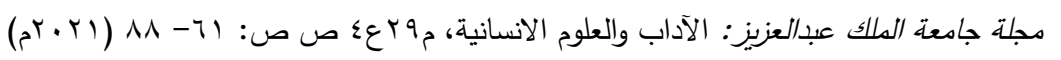

DOI:10.4197/Art.29-4.3

\title{
("مدى جواز إلحاق الصفة بالمضاف إليه في قوله تعالى: (ذو العرش المجيد))
}

\author{
د. داعبد الله بن سالم الثمالي \\ أستاذ مساعد بجامعة الملك عبد العزيز - كلية الآداب \\ قسم اللغة العربية وآدابها
}

مستخلص. كان هدف هذا البحث معرفة مدى استحقاق وصف العرش بالمجيد من جهة المعنى اللغوي، وكذلك الردَّ

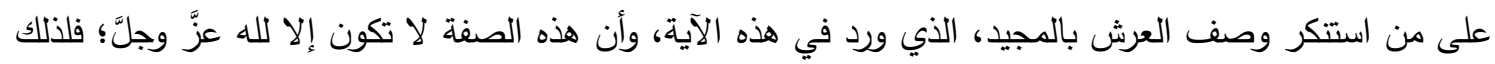
قامت هذه الدراسة على مبحثين رئيسين: المبحث الأول: تتاول معنى لفظتي: (العرش) و (المجيد)، في اللغة والكتاب

والسنة.

المبحث الثاني: ذكر آراء المفسرين في هذه الآية، وأثار إلى ما فيها من قراءات، وبين توجيه النحاة لهذه القراءات، ثم تطرق إلى مسألة إلحاق الصفة بالمضاف والمضاف إليه، وأيهما أحق بها. ومن خلال المبحثين المذكورين توصلت الدراسة إلى عدة مخرجات، منها: - لفظة العرش لها معانٍ عدة في كلام العرب، ويتحدد معنى كلمة (العرش) بحسب ما أضيف إليها. - مادة (عَرَشَ) تدل على الارتفاع والعلو، والعرش أعظم المخلوقات على الإطلاق، كما ثبت بالأدلة.

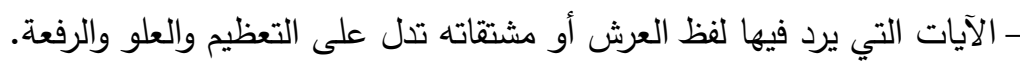

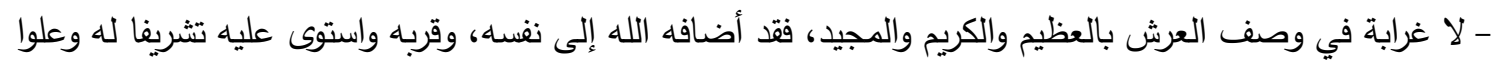
لمكانته. - المجد في كلام العرب ليس صفة مفردة، بل هي عبارة عن صفات كمال مجتمعة، تدل على السعة والكثرة والزيادة، ونهاية الكرم والشرف والفضل، وكثرة العطاء. - المجد ومشتقاته توصف بها المخلوقات والجمادات، كما ورد في كلام العرب، وليس مقتصرا على الخالق سبحانه؛ ولكن مجده سبحانه مغاير عن مجدهم، كما هو الحال في بقية الصفات، كالعظمة والكرم وغيرهما.

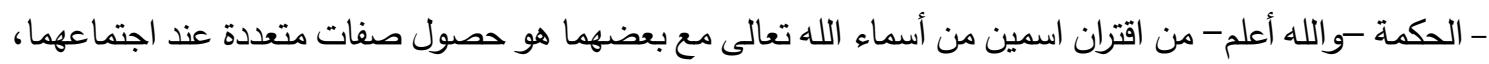
لم تكن لتحصل لو افترقا. ومنها: (الحميد المجيد) و(العزيز الحكيم) وغيرها.

- بعض النحاة يرى جر كلمة (المجيد) على الجوار ، وهذا غالبا للتخلص من وصف العرش بها. - الجر على الجوار مسألة خلافية بين النحاة، ولعلنا نعرج عليها في أبحاث قادمة. - لا يجيز البصريون إضافة الموصوف لصفته، لئلا يلزم إضافة الثيء إلى نفسه. - يستشهد بهذه الآية الكريمة (ذو العرش المجيد) في تعدد الخبر. 
- وجود صفة بعد أكثر من موصوف هو أسلوب جارٍ في العربية، وليس بغريب عنها.

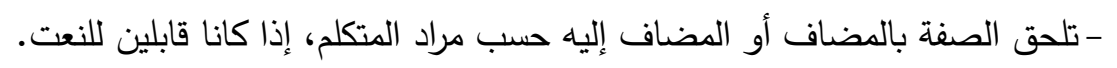

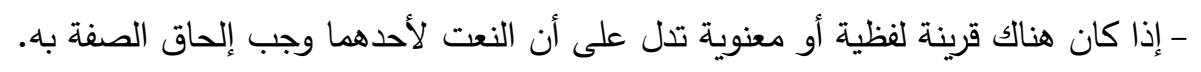

الكريم)، عن مدى جواز وصف العرش وغيره بالمجد. فكأنه يتعجب من وصف العرش بذلك. بل قرأت في كتاب ابن القيم: (التبيان في أيمان القرآن): أنّ بعضهم استشكل قراءة الجر في لفظ:

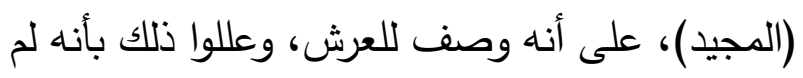

$$
\text { تسمع في صفات الخلق (مجيد). }
$$

ولعل من يقرأ عنوان البحث المتضمن مدى جواز

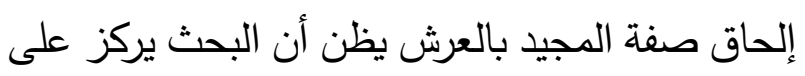

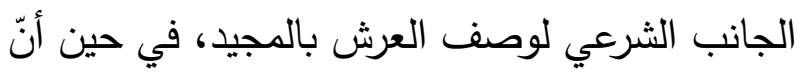

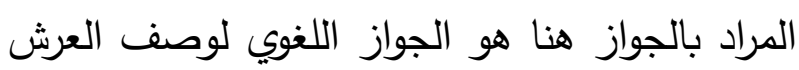

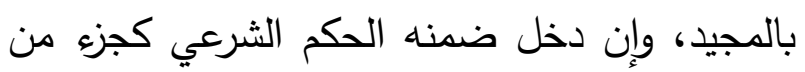

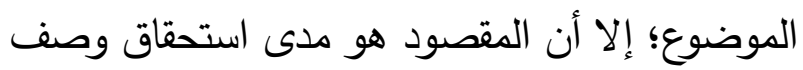
العرش بالمجيد لغة، وهل يسوغ ذلك من جهة المعنى. لذلك وتحقيقاً لهذا الهدف تم الإسهاب في إيراد معاني

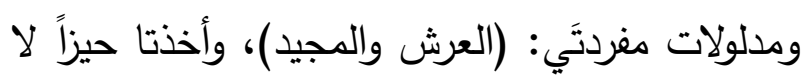

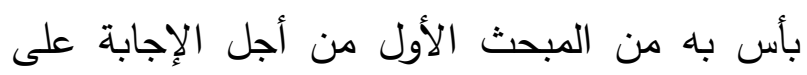

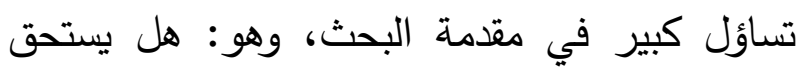

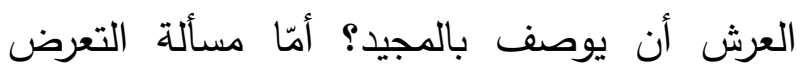

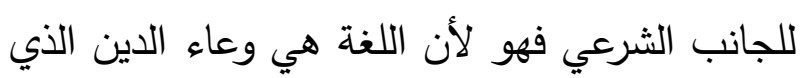
حوى القرآن والسنة، وكذلك لأن التعبد والاعتقاد في الإسلام مرتبط بها وبمدلولاتها. كل ذلك دعاني إلى تقَّمِي معاني كلمتي: (العرش والمجيد)، وتتبع مدلولاتهما في اللغة والثعر ، ورصدي دئي

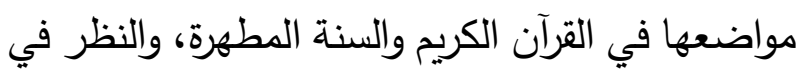

\section{المقدمة}

وصف الله عزّ وجلّ نفسه بالعظيم والكريم والمجيد في

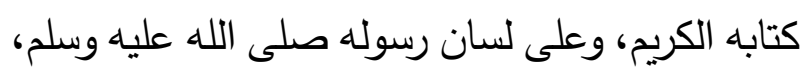
قال تعالى: "ولله الأسماء الحسنى فادعوه بها وذروا الذين يلحدون في أسمائه" [الأعراف: ـ11 1]. ووصف عرشه سبحانه في كتابه العظيم بالصفات نفسها، فهو العظيم والكريم والمجيد. وقد اكتسب هذا

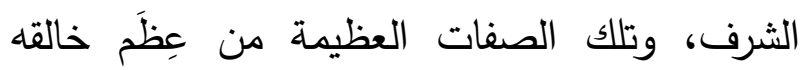
سبحانه، الذي خلقه على هيئة عظيمة، فهو أعظم

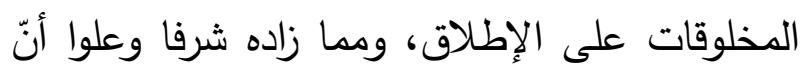
الله سبحانه قد أضافه إلى نفسه في أكثر من آية في القرآن الكريم، مما يدل على عظمته، وقربه من خالقه،

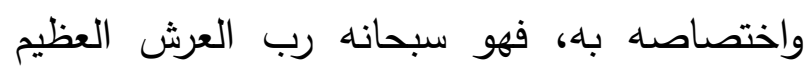
والكريم، وهو سبحانه ذو العرش المجيد.

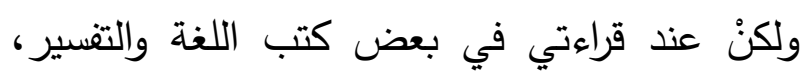
وجدت من أثكل عليه وصف العرش بـ (المجيد)، في

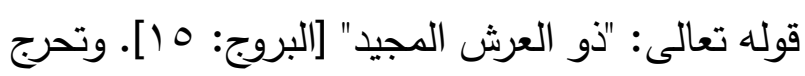

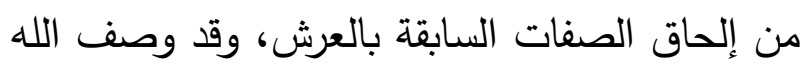

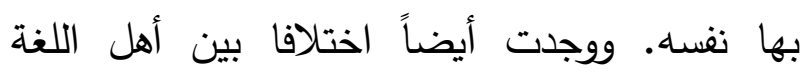
والمفسرين في معنى (المجيد)، وتعدداً في توجيه القراءات فيه وتخريجها. واطُّلعت على تساؤل للدكتور / محمد حسن جبل في وني كتابه: (أصالة الإعراب ودلالته على المعنى في القرآن 
الكبيرة المشهورة؛ ولكنّ هذه الدراسة استقصت مسألة

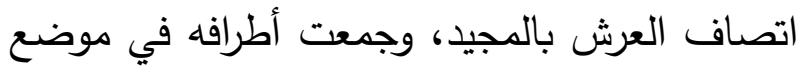
واحد، حيث فصلت في معنى العرش، ومعنى المجيد، وركزت على مدى جواز إلحاق صفات: (العظيم

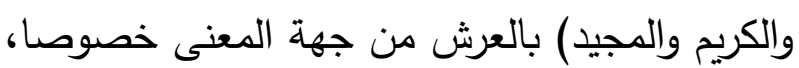
وأيضا بينت توجيهات النحاة لرفع وجر كلمة: (المجيد) في قوله سبحانه: "ذو العرش المجيد". وأخيرا تتاولت الدراسة أحقية المضاف أو المضاف إليه في أخذ الصفة إذا تبعتهما.

لذلك قامت هذه الدراسة على مبحثين رئيسين: أحدهما تناول معاني لفظتي: (العرش) و (المجيد)، في واللغة

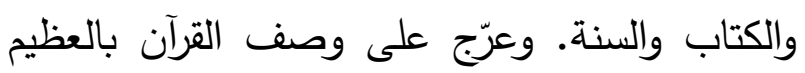
والكريم والمجيد، والآيات التي وردت وفيهاج وهاب، وأقوال المفسرين فيها. وكذلك معاني كلمة المجيد في القرآن والسنة وكلام العرب، وذكر بعض المواضع التي ذُكرتُ فيها.

والمبحث الثاني استقصى آراء النحاة وأقوال المفسرين حول قوله تعالى: (ذو العرش المجيد) وتوجيه قراءاتها.

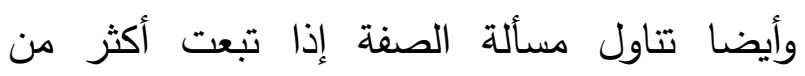
موصوف، وأقوال أهل اللغة فيها.

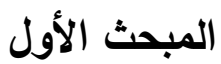
معاني لفظتي: (العرش) و (المجيد) في لغة العرب والكتاب والسنة قبل الكلام عن مدى جواز وصف العرش بالمجيد من

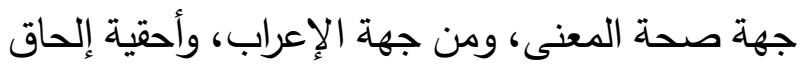
الصفة (المجيد) بالمضاف أو المضاف إليه في قوله
أقوال المفسرين وشراح الحديث في هذا الثأن، وبيان القراءات الواردة في قوله تعالى: (ذو العرش المجيد)،

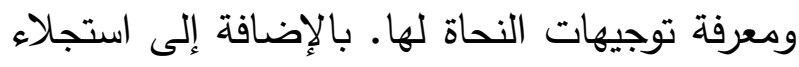

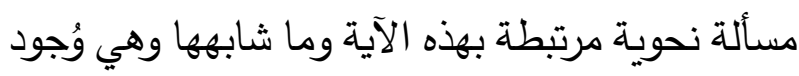
صفة بعد أكثر من موصوف، فبمن تلحق الصفة؟ مرنبه بهده الايه

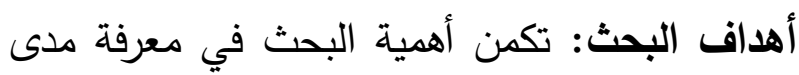
استحقاق وصف العرش بالمجيد من جهة المعنى اللغوي، وذلك بالتركيز على مدلولات مفردتي (العرش والمجيد)، وكذلك جواز إلحاق بعض الصفات الإلاهية

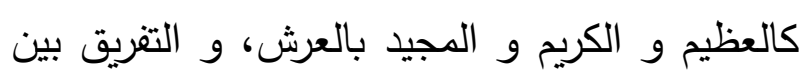
معانيها عندما تكون للذات الإلاهية أو تكون لئن

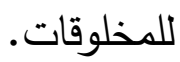

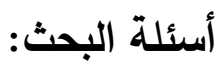

1- هل يستحق العرش أن يوصف بالمجيد من جهة

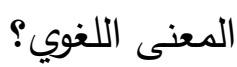
r- ما معنى العرش؟ وما المقصود بـ (المجيد) لغةً واصطلاحاً: r-هل يمكن أن تطلق بعض الصفات الإلاهية كالعظيم والكريم والمجيد على العرش؟ بـ بـن ب-ماهي القراءات الواردة في كلمة (المجيد) في قوله تعالى: "ذو العرش المجيد؟ وما توجيهاتها النحوية؟

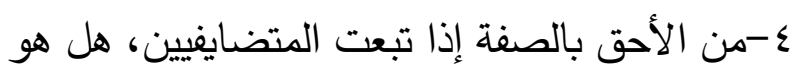
المضاف أم المضاف إليه؟ الاراسات السابقة: الحديث عن العرش وصفاته مبسوط في مؤلفات عدة قديمة وحديثة، منها: كتب التاريخ كالبداية والنهاية، وكتب العقيدة، والتفاسير 
لا يقدر أحد قدره). رواه الحاكم في مستدركه، وقال:

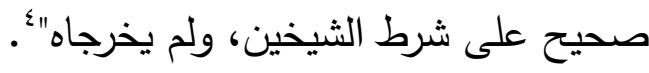

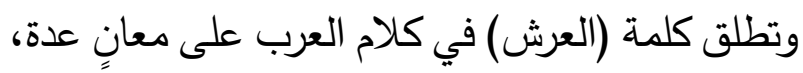
منها:

ا-سرير الملك: يقول ابن منظور: "العرش: سرير الملك، يدلك على ذلك سرير ملكة سبأ، سماه الله عز وجل عرشا، فقال عز من قائل: ( إني وجدت امرأة

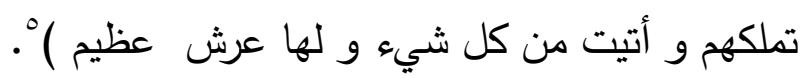
وقد يستعار لغيره، وعرش الباري سبحانه، ولا يحد، و و

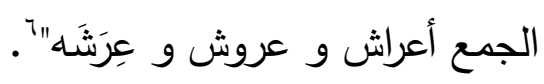

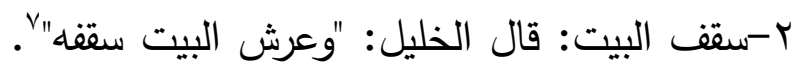
وقال ابن فارس: "ويقال لسقف البيت عرش، قال الله

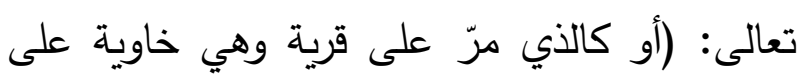
عروشها)؛، والمعنى أن السقف يسقط، ثم يتهافت عليه

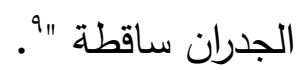
ب-قوام أمر الرجل: قال الخليل: " و عرش الرجل:

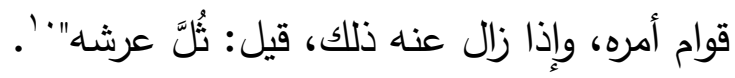
ع-عرش البئر: قال القرطبي: "وعرش البئر : طيُهُها بالخشب، بعد أن يطوى أسفلها بالحجارة قدر قامة، الئرة

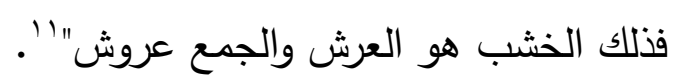
ه-السلطان والملك: ذكر القرطبي أنه قد يأتي العرش

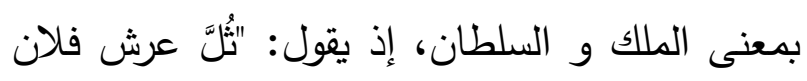

تعالى: "ذو العرش المجيد"، يجدر بنا أن نلمّ بالمعاني

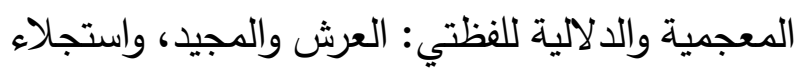
معانيهما في سياقاتهما؛ حتى نستطيع معرفة القول الراجح في هذه المسألة. هل (المجيد) في هذه الآية

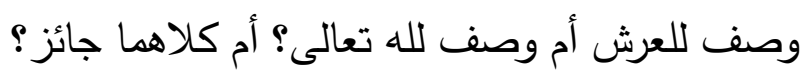
العرش في لغة العرب: قال ابن فارس: "عَ ََشَ، العين و الراء و الثين أصل

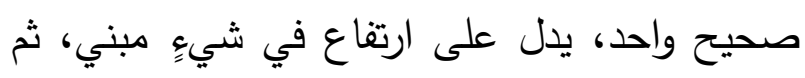
يستعار في غير ذلك"' . من التعريف السابق نلحظ تعلق مادة هذه الكلمة

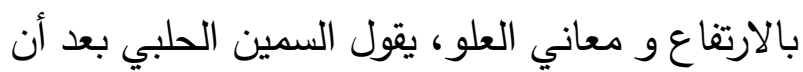

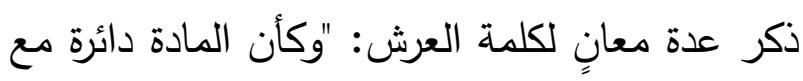
العلو والرفعة "'، لذلك سُمي عرشاً لارتفاعه، ويتضح

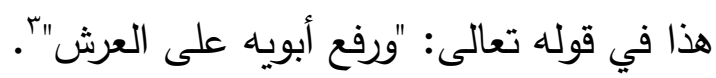

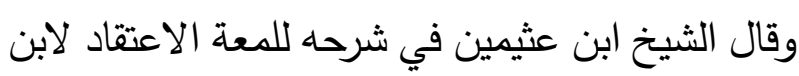
قدامة: "والعرش لغة: السرير الخاص بالملك. وفي

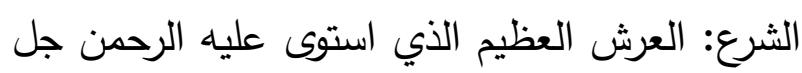
جلاله، وهو أعلى المخلوقات وأكبرها، وصفه الله بأنه عظيم، وبأنه كريم، وبأنه مجيد. والكرسي غير العرش؛ لأن العرش هو ما استوى عليه وليه

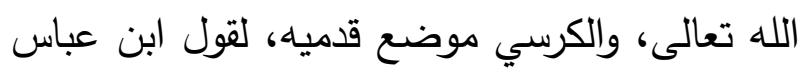

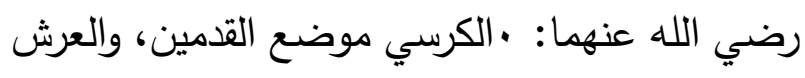

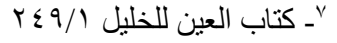

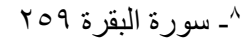

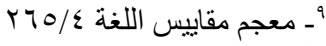

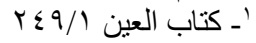

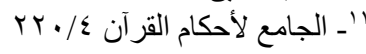

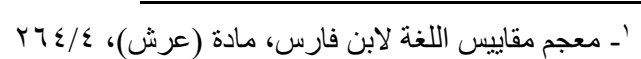

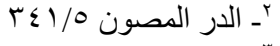

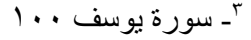

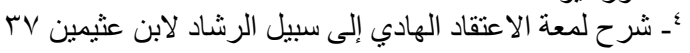

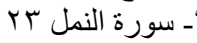

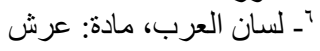


وأيضا أضافه جلّ وعلا لنفسه في مثل قوله تعالى:

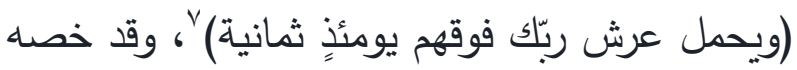

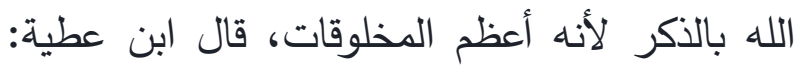

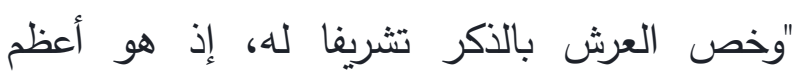

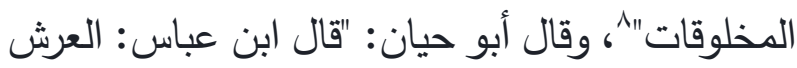

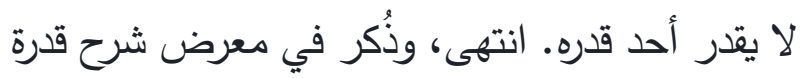
الله وعظمته" وقد بين أهل العلم أن عرش الرحمن هو السرير الذي وعن استوى عليه سبحانه، وهو سرير عظيم ذو قوائم تحمله

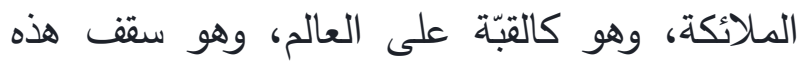

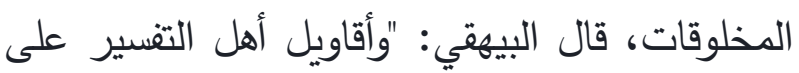
أن العرش هو السرير، وأنه جسم مجسم، خلقه الله

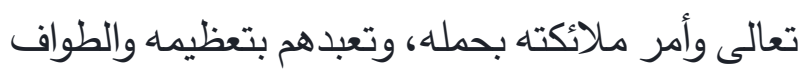

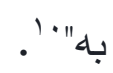
وقال القرطبي: "و العرش مخلوق عظيم شريف كريم ليس فوقه مخلوق، يلي صفحته العليا العدم"، ويلي صفحته السفلى الجنة، فإنه سققها، كما في حديث أبي لي

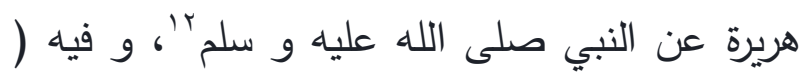
فإذا سألتم الله فاسألوه الفردوس، فإنه أوسط الجنة وأعلى الجنة، وفوقه عرش الرحمن، ومنه تفجر أنهار

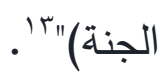

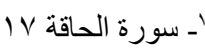

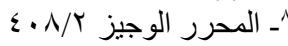

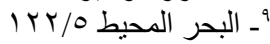

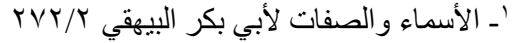

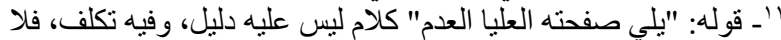

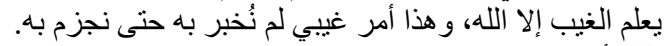

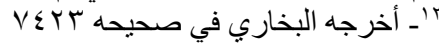

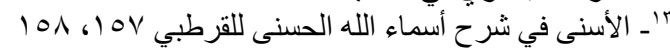

إذا ذهب ملكه وسلطانه وعزه"'، ثم استشهر بييت

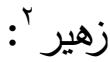

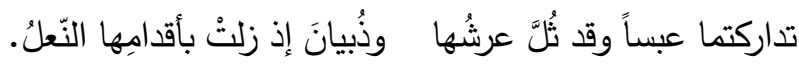

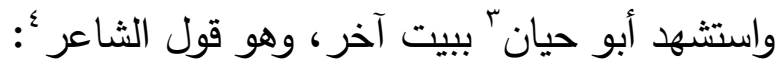

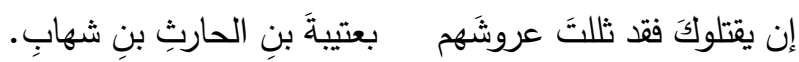

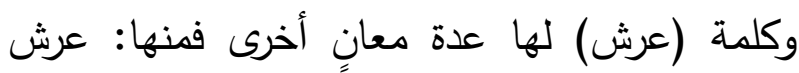

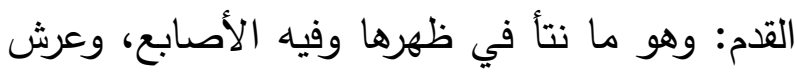

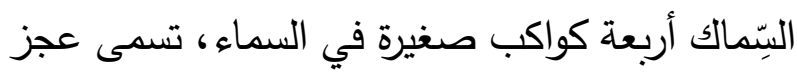

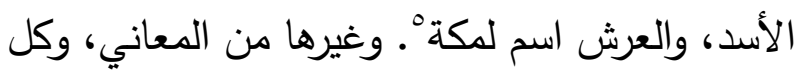

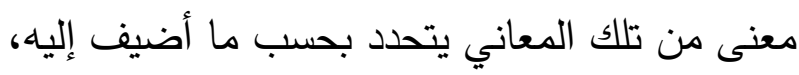

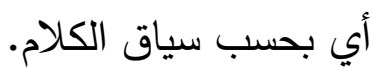
والمقصود هنا في قوله تعالى: (ذو العرش المجيد) أي صاحب العرش. والعرش هنا أي: عرش الرحمن، قال ابن القيم: "فأضاف العرش إلى نفسه كما تضاف إليه

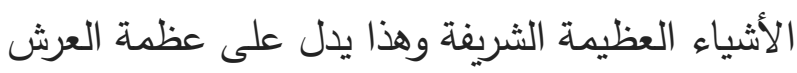
وقربه مناه سبحانه واختصاصه باه، بل يدل على غاية القرب والاختصاص، كما يضيف إلى نفسه بـ (ذو)

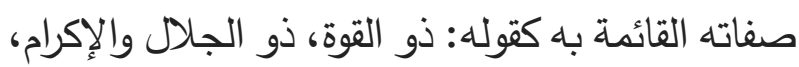
ويقال ذو العزة، وذو الملك، وذو الرحمة، ونظائر ذلك. فلو كان حظ العرش منه حظ الأرض السابعة لكان لا لا

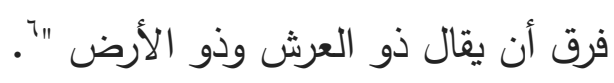

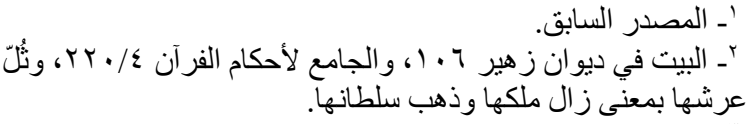

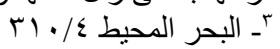

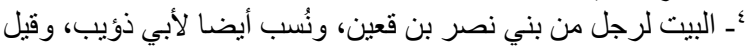

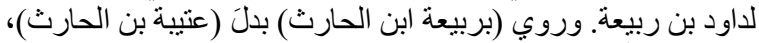

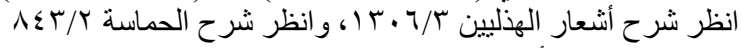

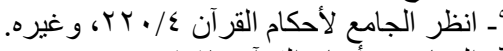

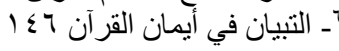


وحول تفضيل قراءة الرفع، نقل أبو حيان في تفسيره عن أبي بكر الأصم قوله: "وهذه القراءة أعجب إليَّ؛

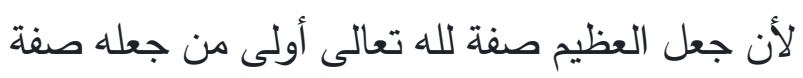

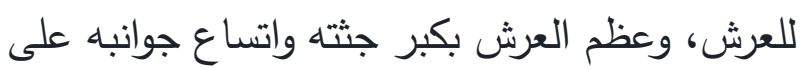

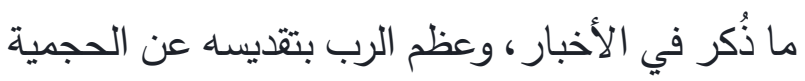

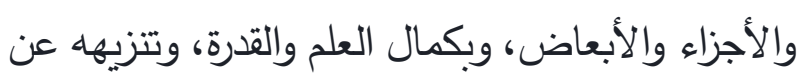

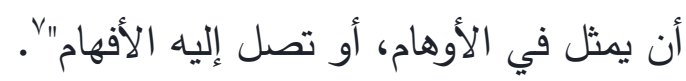

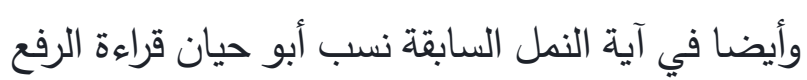

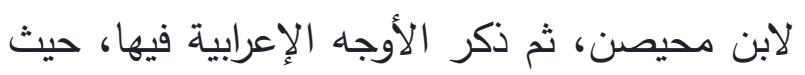

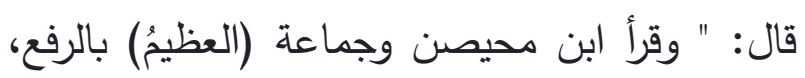
فاحتمل أن تكون صفة للعرش، وقطع على إضمار (هو)، على سبيل المدح، فتستوي قراءته وقراءة

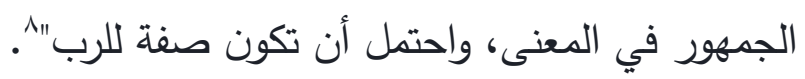

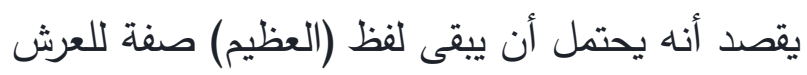

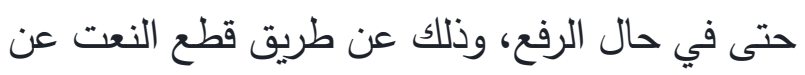

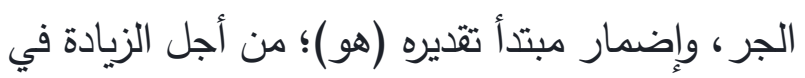
المدح، ويصبح (العظيم) خبرا مرفوعا للمبتدأ المحذوف، والتقدير: هو العظيمُ، وبذلك تتفق قراءة

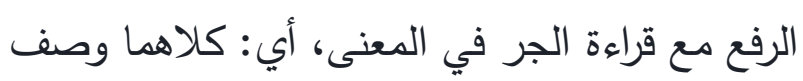
للعرش، والاحتمال الآخر للرفع أن يكون صفة للرب الرب. وقبل هذه الآية في سورة النمل ذُكر لفظ (عظيم) وصفاً

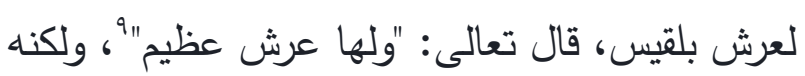

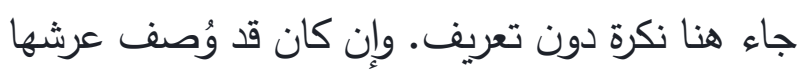

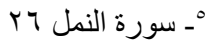

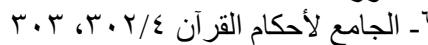

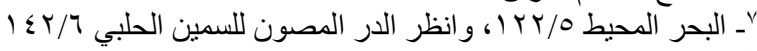

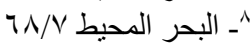

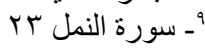

وقال ابن كثير في مقدمة كتابه البداية و النهاية: "و

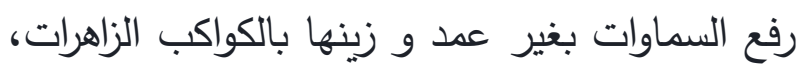
و جعل فيها سراجا و قمرا منيرا، وسوّى فوقهن سريرا

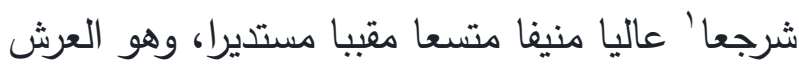

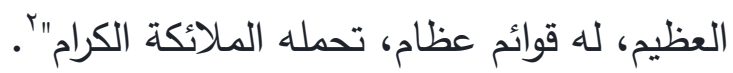
وصف العرش بالعظيم والكريم والمجيد في القرآن وُصف العرش بالعظيم في ثلاث آيات من كتاب الله

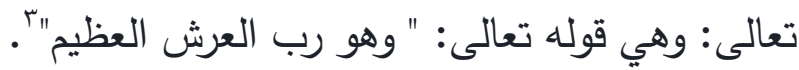
وقوله سبحانه: " قل من رب السماوات السبع ورب لهوب العرش العظيم"؛ ثم قوله عز وجل: " الله لا إله إلا

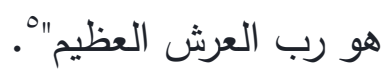
وقبل الاسترسال في سرد أقوال العلماء في هذه الآيات، يحسن الإثارة إلى ملحوظة تحتاج إلى تأمل، وهي أن

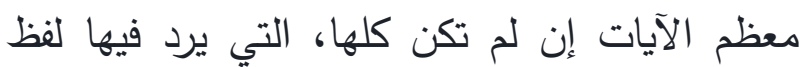
(العرش) أو مشتقاته، تأتي في سياق التعظيم والتتزيه، وتشتمل على معاني العلو والرفعة، ولعل هذا له ارتباط وثيق بمعنى مادة: عرش، التي تدل على الارتفاع والعلو. قال القرطبي: "خص العرش لأنه أعظم المخلوقات،

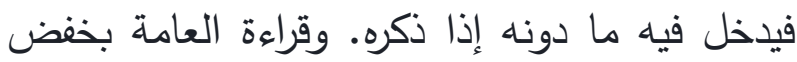

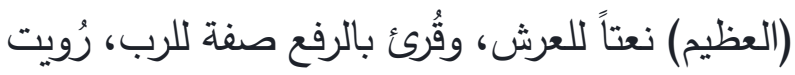

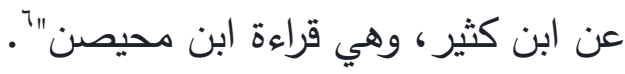
'ـ الثرجع: العالي المنيف، المشرف على غيره، المتتاهي في طوله و ولوه. انظر لسان العرب و القاموس المحيط وغير ها، مادة (شُرجع).

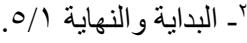

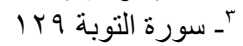

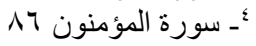


بأوصاف مذهلة في مقاييس البشر'-- والله أعلم ورصف عرش بلقيس بـ(عظيم)، وعرش الله بصحتها- إلا أنه يبقى عرشا من صنع البشر . قال بـ(العظيم) في آيتين من سورة النمل لم يفصل بينهما سوى آيتين فقط، فيه ملحظ لطيف ذكره أبو حيان في معرض حديثه عن قوله سبحانه: (ألّا يسجدوا لله الذي يخرج الخبء)'، هل هو من كلام الله، أم من كلام الهدهد؟ حيث قال: " وقال صاحب الغُنْيان \: لما ذكر الهدهد عرش بلقيس ووصفه بالعظم، ردَّ الله عزّ وجلّ عليه، وبين أن عرشه تعالى هو الموصوف بهذه الصفة على الحقيقة، إذ لا يستحق عرشٌ دونه أن يوصف بالعظمة، وقيل إنه من تمام كلام الهدهد، كأنه استدرك، وردَّ العظمة من عرش بلقيس إلى عرش الله"ه. والمقصود من ذلك هو التفريق بين العظَمتين. وورد وصف العرش بالكريم في قوله عزّ وجلّ: " لا إله إلا هو ربُّ العرش الكريم" . قال الزمخشري: " وصف العرش بالكريم؛ لأن الرحمة تنزل منه والخير والبركة، أو لنسبته إلى أكرم الأكرمين، كما يقال: بيت كريم: إذا كان ساكنوه كراما. وقُرئ (الكريم) بالرفع، ونحوه: (ذو العرش المجيد)"' . أقول وإن كان لكلام الزمخشري وجه إلا أنّ الذي يظهر _و الله أعلم_ أن الكريم هنا ليس بمعنى المعطي الذي تأتي من الخيرات والهبات، وإنما المقصود هو النفيس البهي، صاحب الحسن والجمال والكمال؛ لأن الكرم

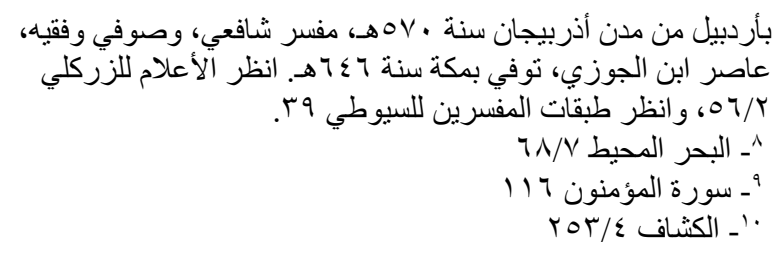

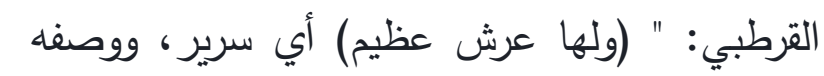

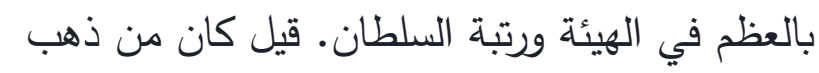

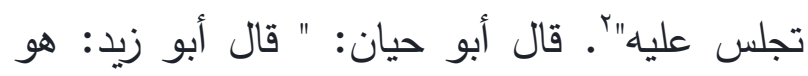

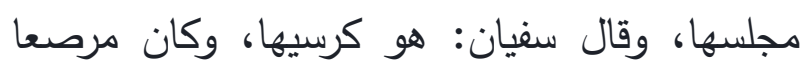

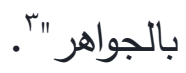
ولعله يرِد على الذهن سؤال وهو : كيف استعظم الهدهد

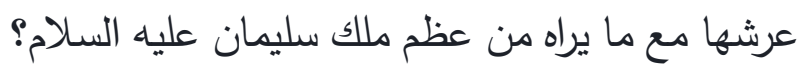
وهذا التساؤل قد أجاب عليه الزخشري، وتبعه أبو حيان، حيث ذكرا أن الهدهد قد يكون استحقر حالها واستصغر أن يكون لها عرش بهذه الهيئة، مقارنة بحال نبي الله سليمان عليه السلام، وقد يكون لهن استعظامه لعرشها لأنه لم يكن لسليمان عليه السلام مثله؛ وإنْ أتي ملكاً عظيما.

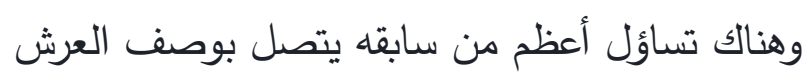

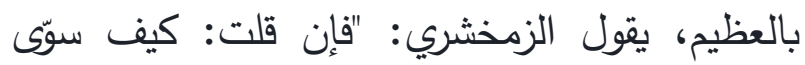

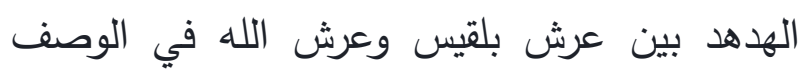

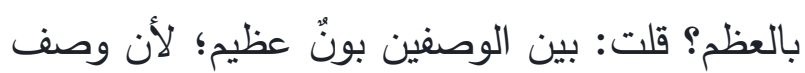

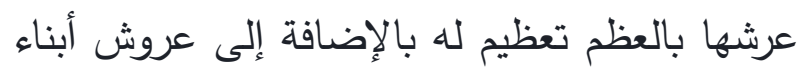
جنسها من الملوك. ووصف عرش الله بالعظم تعظيم

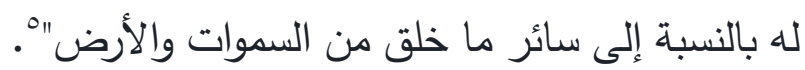

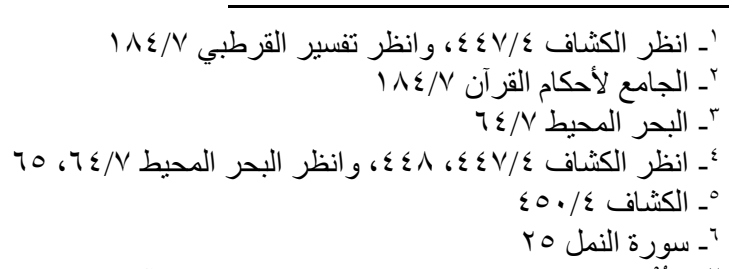

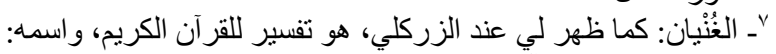

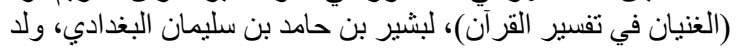


وجل قد أضافه إلى نفسه تشريفا له وعلوا لمكانته؛ فلا يستغرب أن يوصف بالعظيم أو بالكريم أو بالمجيد في

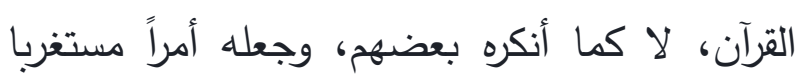
ومردودا. المجيد في لغة العرب اختلف العلماء في لفظ (المجد)! أهو صفة خاصة كالقدرة والعلم؟ أم هو مجموعة صفات تدل على معاني الكمال ونفي صفات النقص. قال القرطبي: " والمجد في كلام العرب عبارة عن اجتماع أوصاف، مع الاتساع و الكثرة في جميعها"؛ وهذا المعنى ذكره أيضاً ابن القيم في معرض حديثه عن أقسام أسماء الله، حيث قال عن القسم الخامس: " الخامس: _ولم يذكره أكثر الناس_ وهو الاسم الدال على جملة أوصاف عديدة لا تختص بصفة معينة، بل دالْ على معانٍ، لا على معنى مغرد، نحو: المجيد، العظيم، الصمد. فالمجيد: من اتصف بصفات متعددة من صفات الكمال، ولفظه يدل على هذا، فإنه موضوع للسعة والزيادة والكثرة ... ومنه (ذو العرش المجيد)، صفة للعرش، لسعته وعظمته وشرفها". قال ابن فارس: " (مجد) الميم والجيم والدال أصل وعله صحيح، يدل على بلوغ النهاية، ولا يكون إلا في

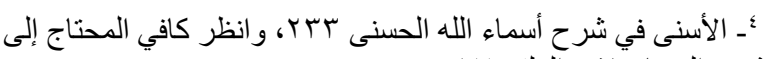

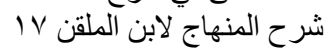

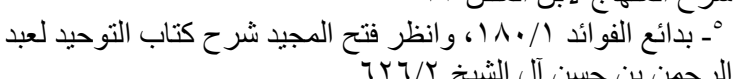

يأتي بمعنى البهاء والحُسن والكمال، والثيء الكريخ هو النفيس عند أهله الجميل في نظرهم؛ لذلك ورد في حديث ابن عباس رضي الله عنهما أنه قال: "قال رسول الله صلى الله عليه وسلم لمعاذ بن جبل حين بعثه إلى اليمن (إنك ستأتي قوما أهل كتاب ...و إياك وكرائم أموالهم)' فكرائم جمع كريمة، وهي النفيسة من أموالهم. لذلك يرد معنى الكريم بمعنى البهي الجميل النفيس، كما ورد في الحديث. والعرش حقيق بهذا المعنى الرفيع. وذكر السمين الحلبي سند قراءة الرفع وتخريجها نحويا، حيث يقول: " وقرأ أبو جعفر وابن محيصن وإسماعيل عن ابن كثير ، وأبان بن تغلب مرفوعا. وفيه وجهان: أحدهما: أنه نعت للعرش أيضا؛ ولكنه قُطع عن إعرابه لأجل المدح، على خبر مبتدأ مضمر ، وهذا جيد لتوافق

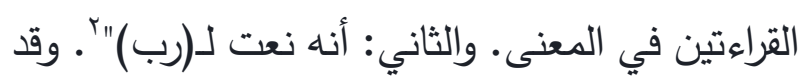
بينت سابقاً عند إعراب (آية النمل ب ب) معنى قوله: (قُطع عن إعرابه)، أي: قُطع النعت عن منعوته. أمَّا صفة المجيد فقد وُصف بها العرش في سورة البروج، في قوله تعالى: "ذو العرش المجيد"'. وهي التي عليها مدار البحث، وسيأتي فيها التقصيل في المبحث الثاني. وفي هذا السياق عندما نرصد هذه الأقوال في صفة

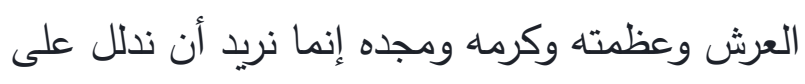

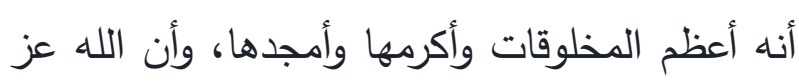

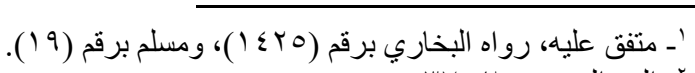

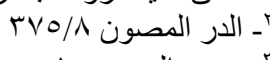

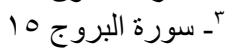


واحد من هؤلاء فضل؛ إلا أن فلانا أفضل، يقال:

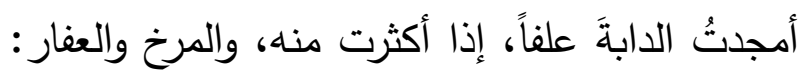
شجرتان تكثر نارهما، يقال: إنهما أخذا النار فأكثرا.

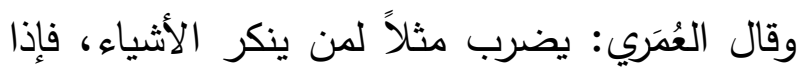

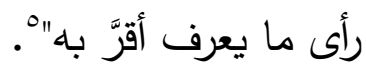

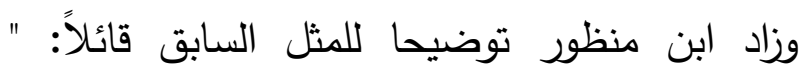

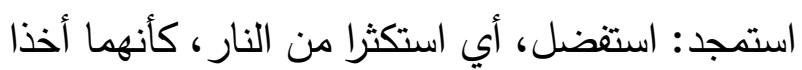
من النار ما هو حسبهما، فصلحا للاقتداح بهما،

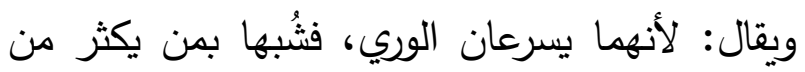
العطاء طلباً للمجد"'.

فإذاً المجد في اللغة هو غاية الكرم و العطاء؛ لذلك

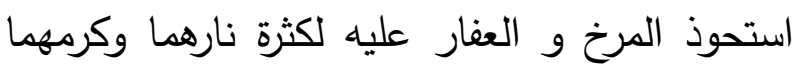
بذلك؛ من أجل ذلك يقال في الأمثال: أرخ يديكَ

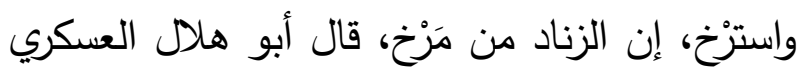

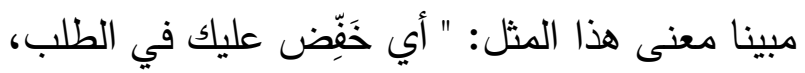
فإن صاحبك كريم، وإذا كانت الزناد من مرخ، أكثُفي بالقليل من القدح"'.ثم ذكر أن أصل المجد الكبَّر

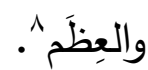
وقال ابن السكيت: " الشرف و المجد يكونان بالآباء، يقال : رجل شريف ماجد: له آباء متقدمون في الثرف. قال: و الحسب و الكرم يكونان في الرجل وإن لم يكن لله آباء لهم شرف" وله
محمود منه، المجد: بلوغ النهاية في الكرم. والله

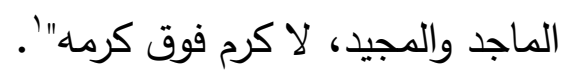

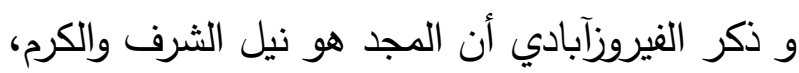

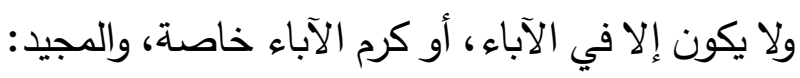
الرفيع العالي و الكريم، والثريف الفعال، و تماجدوا: أي تفاخروا، وأظهروا مجدهم. وأضاف ابن منظور أن المجد يأتي بمعنى المروءة

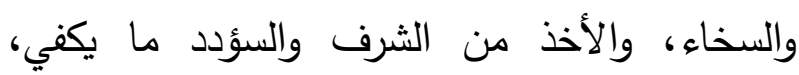
والمجيد: فعيل منه للمبالغة، وقيل: هو الكريم المفضال، وقيل: إذا قارن شرف الذات حسن الفعال سُمي مجدا، والمجيد: من صفات الله عز وجلّ. وأمجدت الإبل: نالت من الكلأ قريبا من الشبح، من منات وأمجدها: ملأ بطونها علفا وأشبعها. وقال بعضهم: " المجد أربعة أركان: الملك والسلطان

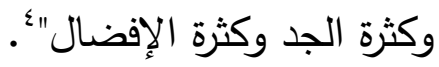
وكلمة (مجيد) ومشتقاتها وردت في القرآن الكريم والسنة المطهرة في أكثر من موضع، وسأفرد لها عنواناً مستقلا، يبين دلالاتها ويكثف معانيها في سياقاتها المختلفة، ويتناول جانبا من إعرابها. وكذلك ورد استعمال جذر هذه الكلمة في الأمثال العربية، ومنه قولهم: (في كل شجرٍ نار ، واستمجد

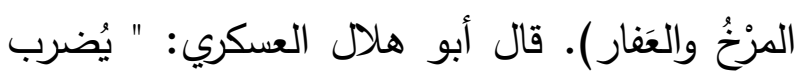
مثلاً في تفضيل الرجال بعضِهم على بعض، أي لكل

' ـ معجم مقاييس اللغة، مادة: (مجد).

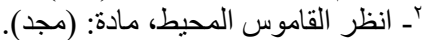

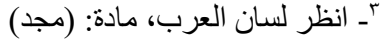
كأ- شرح منهاج البيضاوي، الدسمى: كافي المحتاج إلى شرح المنهاج

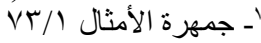

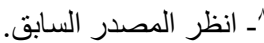
ــ تناج العروس من جو الهر القاموس 10/0 
وبسط النابلسي في موسوعته عدة معانٍ لاسم الله (المجيد) المذكور في هذه الآية، وفي غيرها، ومن هذه المعاني: هو الكريم المفضال، وهو الذي علا وارتفع بذاته، وهو المتناهي في الكمال والعز، وهو واسع الكرم الغني المغني، وهو رفيع الشرف، أي الثريف بذاته، الجليل بأفعاله، الجزيل بعطائه، البالغ المنتهى في الكرم، ثم ثنى بقوله: "و قيل: المجيد: المتناهي في الثرف في ذاته وصفاته وأفعاله، وهو الجليل في نعوته، والجميل

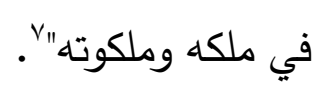

وإعراب (حميد مجيد) في هذه الآية: خبران مرفوعان،

أولّ وثانٍ للحرف الناسخ (إنها)^

الموضع الثاني: قوله سبحانه: " ق والقرآن المجيد "9 ". قال النابلسي: " أي الشريف، فلله الثرف والمجد والعلو والعظمة في ذاته وصفاته وأفعاله، ووصف الله اله تعالى قرآنه بأنه مجيد لكثرة فوائده" '. وذكر أبو حيان أن (القرآن) مقسم به، و (المجيد) صفته، وهو الشريف

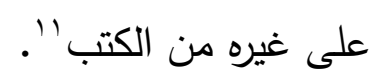
و قال النحاس: " (والقرآن) خفض بواو القسم، (المجيد) من نعته. قال سعيد بن جبير: (المجيد)

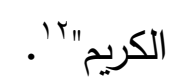

واعترض الهروي على قول ابن السكيت: أن المجد يكون في الآباء، وذكر أن هذا خطأ؛ لأنه قد جاء في

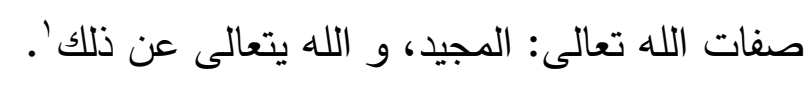
ويظهر لي أن اعتراض الهروي ليس في محله، بل المجد ومشتقاته توصف بها كل المخلوقات والجمادات كما مرَّ بنا، يقول ابن عطية عند وصف العرش بالمجيد: " وهذا على أن المجيد والتمجيد قد يوصف لمف لئ

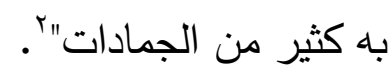
كلمة (مجيد) في القرآن والسنة وردت كلمة (المجيد) في القرآن الكريم أربع مرات: اثنتان منها بدون (ال) التعريف. وأول هذه المواضع: قوله تعالى: (قالوا أتعجبين من أمر الله رحمت الله وبركاته عليكم أهل البيت إنه حميد مجيد)' مجز قال ابن كثير: " أي هو الحميد في جميع أفعاله وأقواله، محمود ممجد في صفاته و ذاته". وقال الدكتور محمد راتب النابلسي بعد أن ذكر الآية:

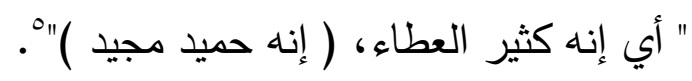
وذكر الزمشري أن الحميد هو الفاعل لما يستوجب به الحمد من عباده، و المجيد هو الكريم، كثير

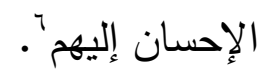


خالويـه، حيث يقول: " قال ابن خالويـه: سمعت ابن الأنباري يقول: معناه: بل هو قرآنُ ربٍ مجيد. كما قال

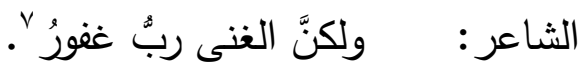

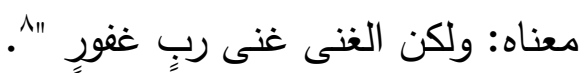

يقصد في الآية أنه حذف مضافاً بتقدير : (رب)، ولعل تأويله هذا -كما ذكرت سابقا- نابع من تحرجه من الن النه وصف القرآن بالمجيد، تعظيما لهذه الصفة من أن يوصف بها غير الله، مع العلم أن كلام الله جزء منه سبحانه، وليس بمخلوق. ثم قال أيضاً: " ويجوز أن يكون من باب إضافة الموصوف لصفته فيكون مدلولُه ومدلولُ التتوينِ ورفعُ (مجيد) واحدا، وهذا أولى لتوافق القراءتين" •. و عقَّب السمين الحلبي على هذا بقوله: " ولكنْ البصريون لا يجيزون هذا؛ لئلا يلزم إضافة الشيء إلى نفسه، ويتأولون ما ورد" '. وهذا الشاهد ورد في مسألة خلافية تناولها ابن الأنباري في كتابه: الإنصاف في مسائل الخلاف، تحت عنوان: إذا جرى الخبر على غير من هو لله، هل يبرز

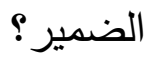
وقد بين محقق الكتاب: محمد محي الدين عبد الحميد فساد هذا التقدير الذي ذكره ابن الأنباري ومن سبقه، وساق وجهين لبيان ذلك؛ ولكن المقام لا يتسع لذكر

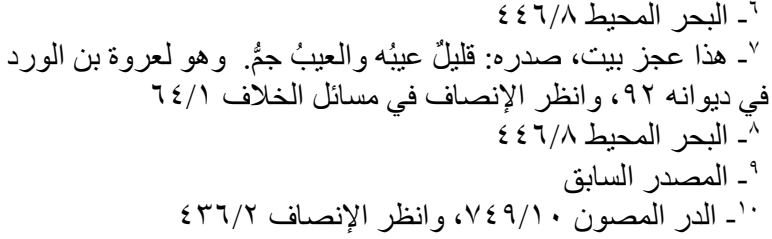

الموضع الثالث: قوله عزّ وجلّ: (ذو العرش المجيد)' . وهذه الآية هي مناط بحثا هذا، وسأفصل فيها في المباحث القادمة. الموضع الرابع: قول الله تعالى: (بل هو قرآن مجيد)'. قال الزمخشري: " شريف عالي الطبقة في الكتب وفي

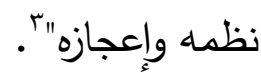
وقال ابن عطية: " وقرأ ابن السميفع اليماني (قرآنُ

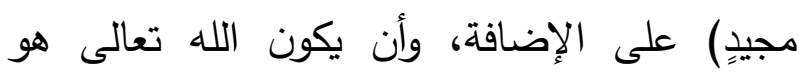
المجيد".يقصد حذُف المضاف، وإقامة المضاف إليه مكانه، و التقدير : بل هو قرآن ربٍ مجيد. ويظهر لي أنّ هذا التأويل كان بسبب تحان ربن تحرجهم من وصف القرآن بالمجيد؛ لأنها من صفات الله، ولا أدري ما الحرج في ذلك إذا عُلم أن القرآن كلام الله، وهو جزء منه سبحانه. بل إن صفة المجيد يمكن أن تطلق الق الق القان على ما دون ذلك من المخلوقات والجمادات، كما ورد على ألسنة العرب. وفي تنسيره للآية قال أبو حيان: " (بل هو قرآن) أي: بل الذي كذبوا به قرآن مجيد، ومجادته: شرفه على لى سائر الكتب بإعجازه في نظمه، وصحة معانيه،

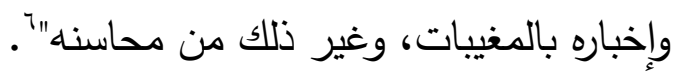
وذكر أبو حيان قراءة الجمهور بالرفع (قرآنّ مجيٌّ)، وخرّجها على أن (مجيد) صفة للقرآن، ثم التقت إلى تلى قراءة الجر وذكر كلاماً في تخريجها يسنده لابن إلى

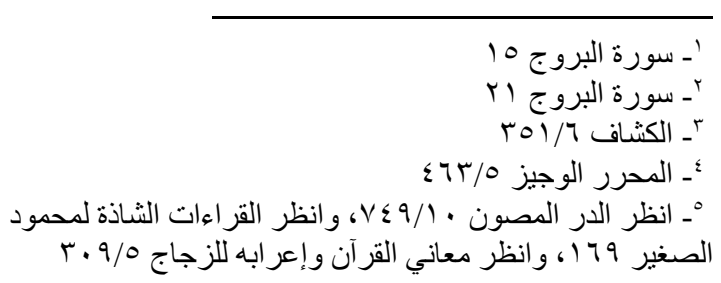


في مقام طلب المزيد، والتعرض لسعة العطاء، وكثرته ودوامه، فأتى في هذا المطلوب باسمٍ يقتضيه، كما تقول: اغفر لي وارحمني، إنك أنت الغفور الرحيم"ه. ومدلول قوله: (حميد مجيد) في هذا الحديث مطابق لما قيل في الآية التي ذكرناها سابقا في [سورة هود " س ] " إنه حميد مجيد". ولفتني نكتة لطيفة نقلها ابن حجر عن أبي عبد الله الحليمي يشير فيها إلى الصلة بين الآية والحديث، والشبه بينهما، في ختمهما بالاسمين الكريمين: (حميد مجيد)، إذ ختمهما بخاتمة واحدة لأن المدلول واحد. حيث بيَّن أن الملائكة دعت لآل إبراهيم في الآية، ودعت لمحمدٍ وآله في الحديث، ومعلومٌ أن محمداً وآله إله من أهل بيت إبراهيم، فكأنه يقول: أجب يا ربّ دعاء الملائكة لمحمد وآله كما أجبت دعاءها لآل إبراهيم؛ لذلك ختم الحديث بما ختم به الآيةج". الموضع الثاني: الحديث القدسي الذي رواه أبو هريرة عن النبي صلى الله عليه وسلم قال: " قال الله تعالى: قسمت الصلاة بيني وبين عبدي نصفين..."، و و موطن الشاهد: (وإذا قال: مالك يوم الدين، قال: مجدني عبدي). قال ابن تيمية: " (مجدني) أي عظمني، وفي رواية: فوض إليَّ عبدي"،

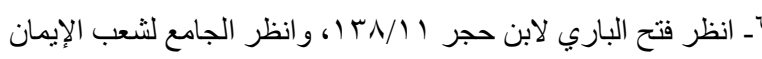

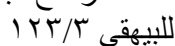

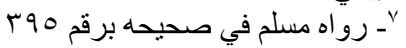

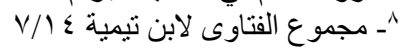

ذلك، كما أنه ليس من صلب بحثنا. فانظر كتاب الإنصاف أم/1.0V/ أمّا في السنة فقد وردت كلمة (مجيد) في أكثر من موضع، منها: الموضع الأول: حديث الصلاة الإبراهيمية عن كعب هوص بن عجرة': " .... اللهم صلّ على محمد و على آل الإل

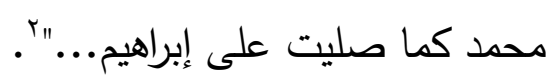
قال فيه: " إنك حميد مجيد ". ذكر ابن القيم تعليلا لختم الصلاة على النبي صلى الله عليه وسلم بهذين الاسمين من أسماء الله تعالى، إذ يقول: " ولمَّا كانت الصلاة على النبي صلى الله عليه وسلم هي ثناء الله تعالى عليه وتكريمه والتتويه به، ورفع ذكره وزيادة حبه وتقريبه كما تقدم، كانت مشتملة على الحمد و المجد، فكأن المصلي طلب من الله تعالى أن يزيد في حمده ومجده، فإن الصلاة عليه هي نوع حمد له وتمجيد" . وفي موطن آخر يشير ابن القيم إلى هذه العلة، و يربط بين الصلاة على الرسول صلى الله عليه وسلم وبين ختمها بهذين الاسمين، أي من باب التعليل للمطلوب بما يناسبه، ويشتمل على معناه ويؤكده، وهذا ما يسمى بالتذييل عند البلاغيين، وهو ختم الكلام بجملة تتضمن مدلوله وتؤكد معناهء. إذ يقول: " وتأمل كيف جاء هذا الاسم مقترناً بطلب الصلاة من الله على رسوله كما علمناه صلى الله عليه وسلم؛ لأنه

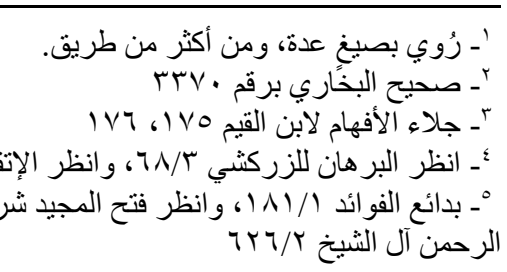


وقال الثيخ بن عثيمين: " الحُسن في أسماء الله تعالى يكون باعتبار كل اسم على انفراده، ويكون باعتبار جمعه إلى غيره، فيحصل بجمع الاسم إلى الآخر كمال فوق كمال، مثال ذلك: العزيز الحكيم، فإن الله تعالى يجمع بينهما في القرآن كثيرا، فيكون كلٌ منهما دالاً على الكمال الخاص الذي يقتضيه، وهو العزة في العزيز، و والحكم و الحكمة في الحكيم، والجمع بينهما دالٌ على كمالٍ آخر، وهو أن عزته تعالى مقرونة

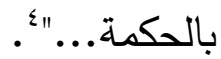
المبحث الثاني تفسير قوله تعالى: (ذو العرش المجيد)، والأوجه

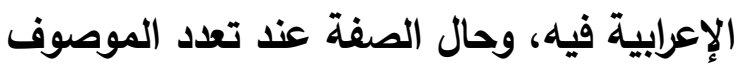
يندرج تحت هذا المبحث عنوانان، أولهما: تفسير الآية وإعرابها. وثانيهما: الصفة وتعدد الموصوف تفسير الآية والأوجه الإعرابية فيها تعددت الأوجه الإعرابية لكلمة (المجيد) في الآية الآنفة الذكر ، فمن قرأ بالرفع عدَّها خبرا للضمير (هو) في قوله تعالى:(وهو الغفور الودود)، أي من باب تعدد الخبر ، ومنهم من ذكر أنها خبر لمبتدأ محذوف تقديره هو، يعود على الضمير السابق، و منهج من قال بأنها صفة مرفوعة للخبر الأول ( الغفور) أو للخبر

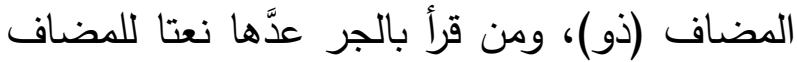
إليه (العرش)،و منهم من جعلها نعتا لـ (ربك)، في

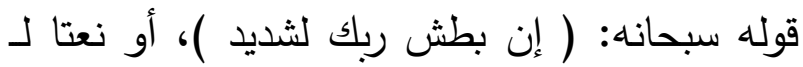

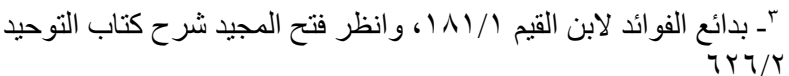

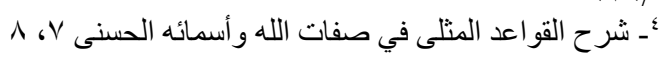

ومن هذا الحديث ندرك أن معنى المجيد هنا هو الملك ذو العظمة والسلطان الكامل والتام، ولا شك أن يوم القيامة وهو يوم الدين، يكون تمام الملك والسلطان والعظمة لله عز وجل، لذلك وافق معنى التمجيد معنى لـى لتحن

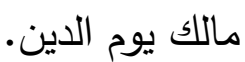
وقال النووي: " قوله: (حمدني وأثنى عليَّ ومجدني)، إنما قاله لأن التحميد: الثناء بجميل الفعال، والتهجيد:

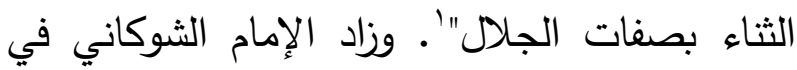

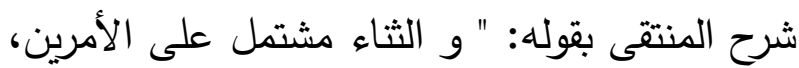
حكى ذلك النووي عن العلماء" . والحكمة الظاهرة لنا- والله أعلم- من اجتماع اسمين من أسماء الله تعالى مع بعضهما هو حصول صفات متعددة عند اجتماعهما، لم تكن لتحصل لو افترقا. يقول ابن القيم عند تصنيفه لأقسام أسماء الله الحسنى: " السادس: صفة تحصل من اقتران أحد الاسمين والوصفين بالآخر، وذلك قدر زائد على مفرديهما، نحو: الغني الحميد، العفو القدير، الحميد المجيد، وهكذا عامة الصفات المقترنة، والأسماء المزدوجة في القرآن، فإن الغني صفة كمال والحمد كذلك، واجتماع الغنى مع الحمد كمال آخر ، فله ثناء من غناه، وثناء من حمده، وثناء من اجتماعهما، وكذلك: العفو القدير،

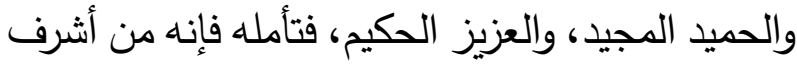

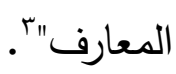


تعدد الخبر لمبتدأ واحد، بل من باب تعدد الصفات بعد الخبر الأول؛ أي: أن (الغفور) هو الخبر ، وما بعده صفات لهذا الخبر ، ومن ضمنها (المجيد)، وعليه يُخَرَّج مذهب ابن عصفور كما أشار إلى ذلك السيوطي '، أو من باب تعدد الأخبار لمبتدءات محذوفة مقدرة، و ليس لمبتدأ واحد، و عليه يُخَرَّج مذهب الخليل •. وأجاز هذا التأويل ابن الأنباري`، وقد جوز الآلوسي الوجهين أي أن تكون أخبارا لمبتدآت محذوفة أو صفات للخبر الأول . وكذلك ضعف الفخر الرازي أن تكون هذه الآية من الن باب تعدد الخبر ، بل يرى أن قوله تعالى: (الودود، ذو العرش، المجيد) صفات لله الغفور • و يقول عن قراءة الرفع: " وهو اختيار أكثر القراء والمفسرين لأن المجد من صفات التعالي والجالا، وذلك لا يليق إلا بالله سبحانه، والفصل والاعتراض بين الصفة والموصوف في هذا النحو غير ممتنع "’'. وذكر ابن زنجلة أن من قرا بالرفع جعله صفة لـ (ذو)، ثم قال: " والمجد هو الشرف، فأسندوه إلى الله تعالى إذ كان أولى أن

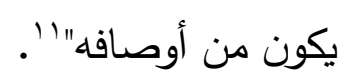

ذكر ابن المنير أن صفة المجيد لا تتعلق بالعرش، وعلق على كلام البخاري بقوله: " وكلما ذكره مشتمل على ذكر العرش إلا قوله: وقال ابن عباس: (المجيد)

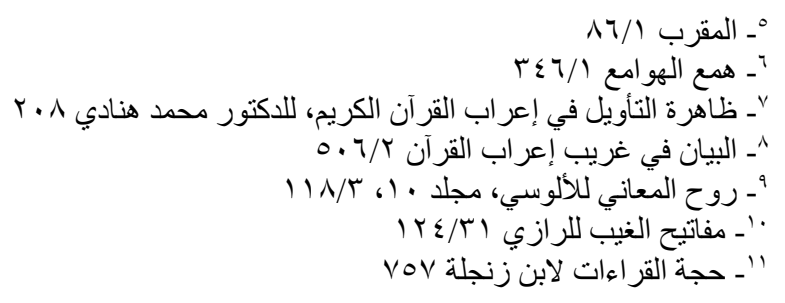

(ذي) عند من قرأ: (ذي العرش المحيد)، ومنهم من خرَّج قراءة الجر على الجوار - الج كل هذه الأقوال والآراء والتوجيهات النحوية سأُفَمِّل فيها وأسندها إلى أصحابها، وسوف أوثقها من مصادرها الأصلية، مبيناً رأي من استشكل قراءة الجر ؛ على أن (المجيد) صفة للعرش، واستتكر كيف يوصف مه الهف العرش بـ (المجيد)، وموضحاً في المقابل وجهة النظر الأخرى التي أجازت وصف العرش بالمجيد، ثم في آخر المطاف مرجحاً لما يظهر لي رجحانه. قال النحاس بعد أن ذكر قراءة الجر : "فبعض النحوين يستبعد الخفض؛ لأن المجيد معروف من صفات الله، جلّ و عزّ، فلا يجوز الجواب في كتاب الله، بل على مذهب سيبويه لا يجوز في كلام و لا شعر، و إنما هو غلط في قولهم: هذا جحر ضبٍ خَرِبٍ '، و نظيره في الغلط الإقواء؛ و لكن القراءة بالخفض جائزة على غير الجوار، على أن يكون التقدير : إن بطش ربك المجيدِ، نعت" · . و قد قرأ بالرفع جعفر ونافع وابن كثير وأبو عمرو وعاصم، وقرأ بالجر يحيى بن وثاب وحمزة

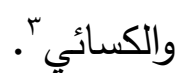
ولعلنا نشير هنا إلى مسألة الاستشهاد بهذه الآية في

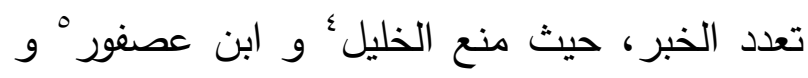
كثير من المغاربة أن يكون رفع (المجيد) من باب 
لجلالته و عظيم قدره، كما أشار إليه الراغب، و لذلك وُصف بالكريم في سورة قد أفلح"؛ و قال ابن عطية: " (المجيدِ) بخفض الدال صفة للعرش، و هذا على أن المجيد و التمجيد قد يوصف به كثير من الجمادات، و قد قالوا: مجدت الدابة إذا سمنت، و أمجدتها إذا أحسنت علفها، و قالوا: في كل شجرٍ نار، و استمجد المرخ و العفار : كثرت نارهما، و قرأ الباقون و الجمهور: (ذو العرش)، و روى ابن عباس: (ذي العرش)، نعتاً لقوله: (إن بطش ربك)"ه و ذكر أبو علي الفارسي أن من جرَّ (المجيد) من النحاة فهم على ضربين، حيث يقول: " فمن النحوين من جعله وصفا لقوله: (ريّلك) في: (إن بطش ربك لشديد)، ، قال: و لا أجعله وصفا للعرش، و منهم من قال: هو صفة للعرش" . وقال مكي: " قوله: (ذو العرش المجيد)، من خفضه جعله نعتا للعرش. و قيل: لا يجوز أن يكون نعتا للعرش؛ لأنه من صفات الله جلّ ذكره، و إنما هو نعت للرب في قوله: (إن بطش ربك لشديد، و من رفعه جعله نعتا لـ ( ذو ) أو خبرا بعد خبر" ل. وذكر ابن القيم أن هناك من استشكل قراءة الجر (المجيد)،، على أنها وصف للمخلوقات، حيث يقول: " ومن قرأ المجيد بالكسر فهو صفة لعرشه سبحانه، وإذا كان عرشه مجيدا فهو سبحانه أحق بالمجد. وقد استشكل هذه القراءة بعض الناس، وقال: لم يُسمع
الكريخ، و (الودود) الحبيب، فقال: حميد مجيد، كأنه فعيل من ماجد، ومحمود من حميد. فهذا الفضل لا لانل يتعلق بالعرش، ولكنه نبه على لطيفة، و هي أن المجيد في قوله: (ذو العرش المجيد)على قراءة الكسر لا يتخيل أنها صفة العرش؛ وأنه بذلك قديم، بل هي صفة الحق، بدليل قراءة الرفع، وبدليل اقترانها بالودود، و هي صفة الحق، فيكون الكسر على الجوار حينئذ؛ "'. و علل ابن حجر ذلك بقوله: : " لتجتمع القراءتان على معنى واحد، و يؤيد أنها عند البخاري صفة الله تعالى ما أردفه به، و هو يقال: حميد مجيد إلخ، و يؤيده حديث أبي هريرة، الذي أخرجه الدار قطني بلفظ: إذا قال العبد باسم الله، قال الله تعالى: مجدني عبدي" - مبي و لكن الحافظ ابن حجر في الفتح بعد أن ذكر قول ابن المنير و ما دلل به من رأي البخاري بأن المجيد

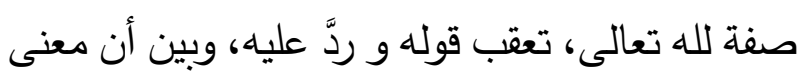
المجيد هو المبالغة في المجد، و هو الثرف القديم، و أن الماجد من له آباء متقدمون في الشرف، ثم ذكر قول الراغب: ( المجد السعة في الكرم و الجلالة، و أصله قولهم: مجدت الإبل، أي: وقعت في مرعى كثير واسع، و أمجدها الراعي، و وصف القرآن المجيد لما يتضمنه من المكارم الدنيوية والأخروية)؛'، و ختم بقوله: "و مع ذلك كله، فلا يمنع وصف العرش بذلك؛ 
أو أنه صفة لربك فتكلف شديد وخروج عن المألوف في اللغة من غير حاجة إلى ذلك"ه أ.

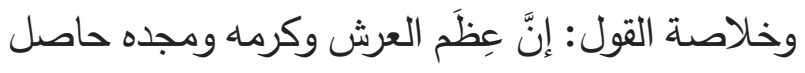
من عِظَ وكرم ومجد خالقه سبحانه الذي استوى عليه، فأكسبه ذلك الثرف وتلك المنزلة بنسبته إليه، وبقربه منه، واستوائه عليه، فلا عجب أن يوصف بهذه الأوصاف، بل العجب أن نجد من ينكر ذلك، أو أو ئه يتحرج من وصفه بها، وإن كان هذا عذد بعضهم من بن

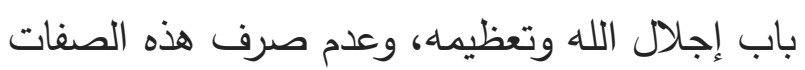

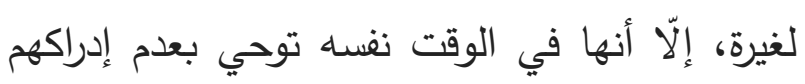
لعظمة هذا المخلوق وضخامته، وبديع صنح الله فيه.

\section{الصفة وتعدد الموصوف}

هذه الآية التي قام عليها البحث، وهي قوله تعالى: "

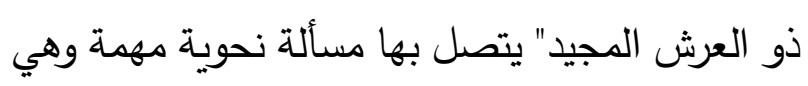

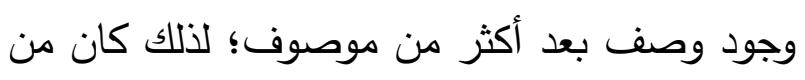
المناسب إيراد هذه المسألة هنا لصلتها الوثيقة بالآية الآنفة الذكر كما ذكرت، وأيضا لإعطاء فكرة عامة عن مضمونها دون التشعب في تفاصيلها؛ حتى نلم بأطرافها من جهة، ومن جهة أخرى كي ندلل على أن هذا أسلوب دارج ومعروف في كتاب الله. الصفة في هذه الآية المذكورة تبعت موصوفين، ولابد أن تلحق بأحدهما، فالصفة هي قوله الاية: (المجيد)، والموصوفان هما المضاف أو المضاف إليه، وهما:

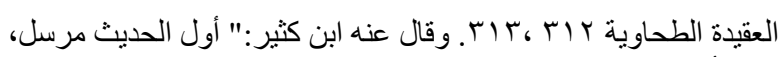

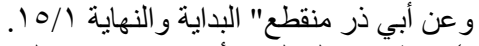

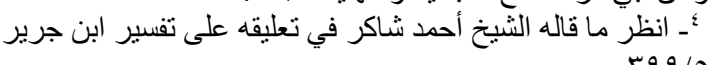

$$
\begin{aligned}
& \text { r } 99 / 0
\end{aligned}
$$

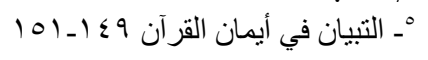

في صفات الخلق مجيد، ثم خرجها على أحد الوجهين:

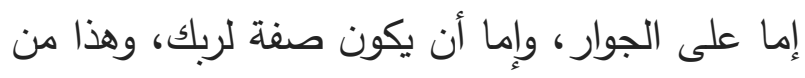
قلة بضاعة هذا القائل"'. بل من المتأخرين من تساءل عن صحة وصف العرش و غيره من المخلوقات بالمجد، يقول الدكتور محمد الدمد حسن حسن جبل بعد أن تحدث عن وصف العن العرش العكات

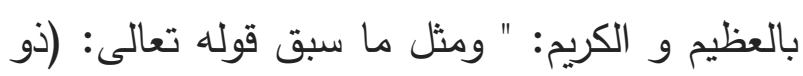
العرش المجيد)، حيث قُرئ لفظ (المجيد) بالجر ، صفة فئة

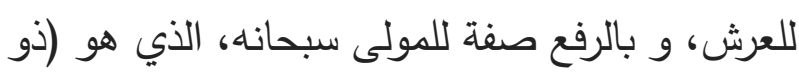

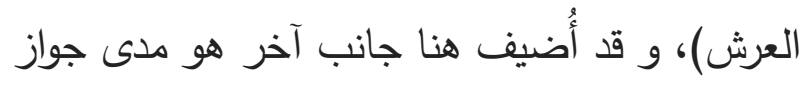
وصف العرش وغيره بالمجد"'. وقد بيَّن ابن القيم أن العرش حقيق بهذا الوصفي كئ كيف

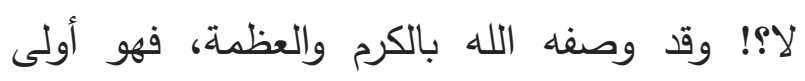
المخلوقات أن يوصف بهذه الوصف، لما له من سعةٍ وحُسنٍ وبهاءٍ، ثم قال: " ولا يقدر قدر عظمته وحسنه لونه وبهاء منظره إلا الله. ومجده مستفاد من مجد خالقه

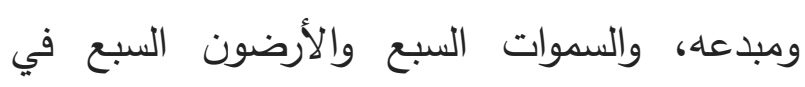
الكرسي الذي بين يديه كحلقة ملقاة في أرض فلاة، والكرسي فيه كتلك الحلقة في الفلاة'، قال ابن عباس: السموات السبع في العرش كسبعة دراهم جعلن في

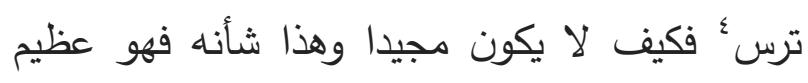
كريم مجيد. وأما تكلف هذا الدتكلف جره إلى الجوار

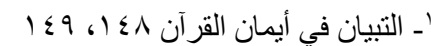

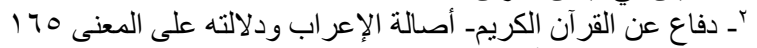

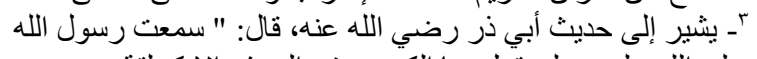

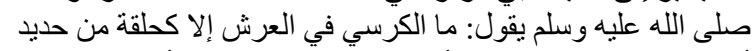

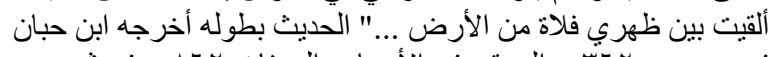

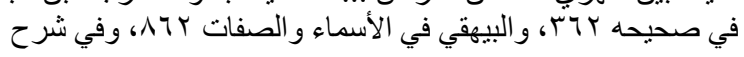


لمراد المتكلم في ذلك، فهو الذي يوجه النعت للمضاف أو للمضاف إليه، إن كانا قابلين للنعت، فإن كان هناك قرينة لفظية أو معنوية تدل على أن النعت لأحدهما

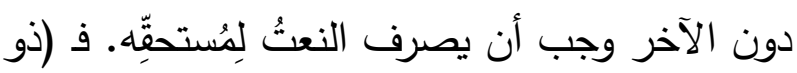
الجلال والإكرام) صفتان تصلحان في المعنى أن تلحق بالمضاف أو المضاف إليه؛ ولكنهما حُدِّدا في الآيتين بالضبط الإعرابي لكي نعرف الموصوف الذي أراده المتكلم سبحانه. ففي الآية الأولى وُصف بهما وجه الرب سبحانه؛ وهو فاعل مرفوع فجات الصفة (ذو) مرفوعة بالواو؛ لأنها من الأسماء الخمسة. وفي الآية الثانية وُصف بهما الرب سبحانه، ولفظ (ربك) جاء مضافاً إليه مجرورا، فأتت الصفة (ذي) مجرورة بالياء، فعرفنا بالإعراب صاحب الصفة في الآيتين. ومما لا ريب فيه أن وجود الصفة بعد أكثر من موصوف هو أسلوب جارٍ في العربية، وليس بغريب عنها، وأمثلته كثيرة في القرآن. ومنها ما تطرقنا إليه من آيات في هذا البحث، مثل قوله تعالى: "رب العرش العظيم" و "رب العرش الكريم"، وغيرهما. وقد ألمت الدراسة بأقوال العلماء وآرائهم في تفسير معاني هذه الآيات، وكذلك بينت توجيهاتهم لقراءتي الرفع أو الجر في الصفات التي لحقت بلفظ (العرش). ولعلنا هنا نذكر بعض المواضع في القرآن التي تلحق فيها الصفة بالمضاف أو المضاف إليه، ونبيّنُ مَنْ هو
(ذو العرش)، ويجوز لكلٍ منهما أن تلحق به هذه الصفة ما دام المعنى يسمح بذلك، فذ(المجيد) إما أن يكون صفة لـ(ذو)، أو لـ(العرش). وقد ذكرنا تقصيل ذلك في ثنايا البحث. ذكر ابن هشام في المغني مسألة، تكلم فيها عن إلحاق الصفة بأحد المتضايفين أو الموصوفين، حيث تحدث عن قوله تعالى: "سبح اسم ربك الأعلى"'، فقال: "يجوز فيه كون الأعلى صفة للاسم، أو صفة للرب، و أما نحو: (جاءني غلام زيد الظريف) فالصفة للمضاف، ولا تكون للمضاف إليه إلا بدليل؛ لأن المضاف إليه إنما جيء به لغرض التخصيص، ولم يؤت به لذاته"r، ثم أشار بمثال إلى أن الإضافة لـ (كل) تتصرف فيها الصفة للمضاف إليه، لأن المضاف جاء بقصد التعميم. ^ّوقد ذكر هذه المسألة أيضا الدكتور عباس حسن في النحو الوافي.؛ ويظهر لي أن ما ذكره ابن هشام أمر معتبر على قدر التفصيل الذي بينه؛ ولكنّ الضابط بوجه عام في مسألة التحاق الصفة بالموصوف هو مراد المتكلم. فلا يمنع أن يكون النعت للمضاف أو المضاف إليه إذا اتفقا حقيقة وعقلًا أن يُنعتا به، وشاهد ذلك قوله عز وجل: "ويبقى وجه ربك ذو الجلال والإكرام" ، وقوله سبحانه: "تبارك اسم ربك ذي الجلال والإكرام"، فنحن نرى أن النعت في الآيتينِ يصلح فيه أن يكون وصفًا للمضاف والمضاف إليه، واختيار أحدهما أن يكون منعوتًا يعود 
ومسألة الجر بالمجاورة فيها خلاف بين النحاة، فمنهم من يجيزها، كما مرَّ بنا في هذه الآية على لسان الزخشري وغيره، ومنهم من ينكرها ولا يقرها كسيبويـهُ، وقد مرَّ بنا طرف من كلامه فيها عند إعراب قوله تعالى: (ذو العرش المجيد)، وتبعه السيرافي وابن جني وغيرهما. وبعضهم قد يجيزها في المسموع عن العرب فقط، ولا يقبل القياس عليها، كما ذُكر عن وئن الفراء.

ونحن في هذا البحث لسنا بصدد الحديث عنها، وتقصي آراء العلماء فيها، وإنما جاءت عرضا لمناسبتها في الآية. المثال الثاني: قال الله عزّ وجلّ "فلما أتاها نودي من شاطئ الواد الأيمن" . قال ابن عطية: "(الأيمن) يحتمل أن يكون من الئمن، صفة للوادي، أو للشاطئ، ويحتمل أن يكون المعادل لليسار، فذلك لا يوصف به الشاطئ؛ إلا بالإضافة

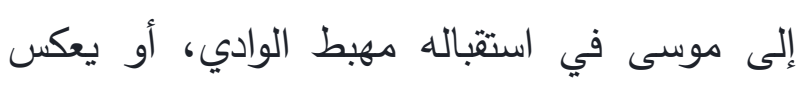
ذلك"، . وذكر ذلك أيضا أبو حيان ج. وإن كان ابن عطية وأبو حيان لا يريان للجبل أو لودئ دان للوادي يمنة ولا يسرة؛ كما في المثال الأول، فإن القرطبي في هذه الآية ذكر خلاف ذلك، حيث قال: "(الأيمن) أي عن يمين موسى ، وقيل: عن يمين

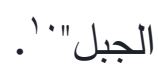

الأحق بالظفر بها، وذلك من خلال أقوال علماء اللغة والتقسير الت المثال الأول: يقول الله عزّ وجلّ: " وناديناه من جانب

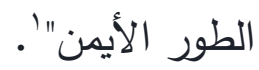
قال أبو حيان: " الظاهر أن (الأيمن) صفة للجانب؛ لقوله في آية أخرى: (جانب الطور الأيمنَ) بنصب (الأيمن) نعتاً لـ (جانب الطور)، والجبل نفسه لا يمنة له ولا يسرة؛ ولكن كان على يمين موسى بحسب وقوفه

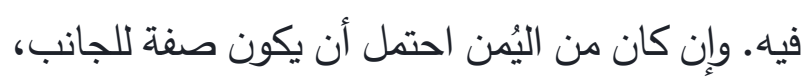

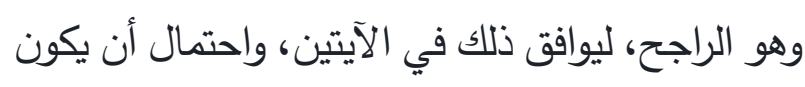

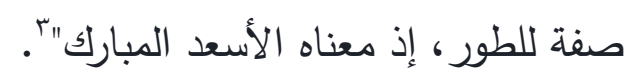
ومن جمال التوجيه النحوي وحسنه في هذ الآية يظهر لنا كيف عضدت الآية أختها في إظهار المعنى، وكيف أُلحقت الصفة بمن هو أحق بها. فنصْبُ الصفة الصنا نفسِها في آية الطور بيَّنت لنا من صاحبها في آية

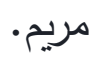
وأيضا من جمال اللغة وسعة دلالاتها أن اختيار معنى: اليُمن لكلمة (الأيمن) أجاز للصفة وفتح لها الباب أن تلتحق بأيٍ من المتضايغين. وفي قراءة الجر لكلمة (الأيمن) في آية الطور : (ول) واعدناكم جانب الطور الأيمنَ) ذكر الزمخشري أنها جُرت على الجوار • ع

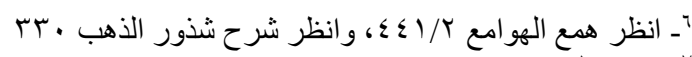

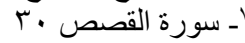

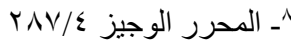

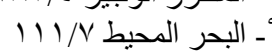

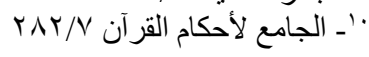

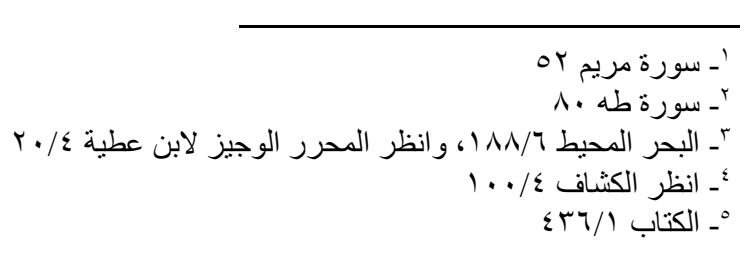


البداية أذكر معنى: السندس والإستبرق؛ حتى تتضح

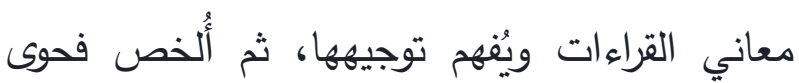
توجيه القراءتين وأذكر ما قاله المفسرون وأهل اللغة تونة فيهما.

ذكر ابن عطية والقرطبي أن معنى السندس: الرقيق من الديباج، والمرتفع منه، أو الحرير الأخضر ـ أمّا

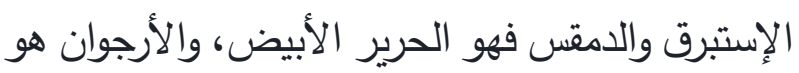

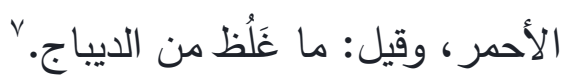

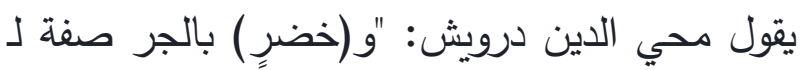

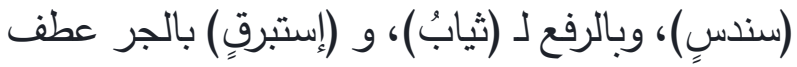

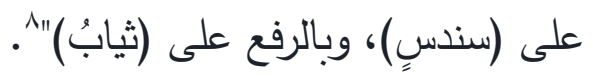

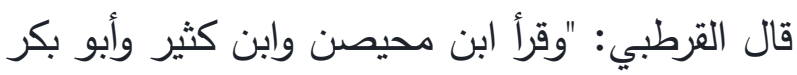
عن عاصم (خضرٍ) بالجر على نعت السندس، (وإستبرقُّ) بالرفع نسقاً على الثياب، ومعناه: عاليهح

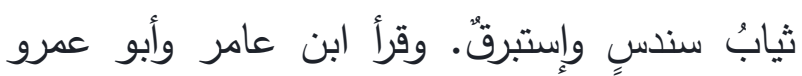

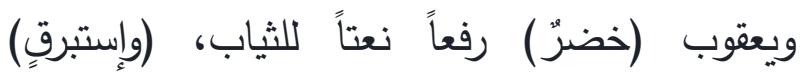
بالخفض نعتاً للسندس، واختاره أبو عبيد، وأبو حاتم

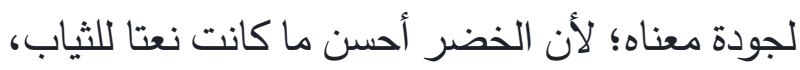

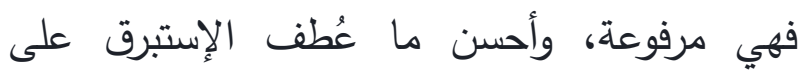
السندس، عطف جنسٍ على جنس، والمعنى: عاليهم ثيابٌ خضرٌ من سندسٍ وإستبرقٍ، أي من هذين ونسي

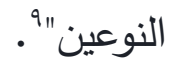

$$
\begin{aligned}
& \text { لـ انظر المحرر الوجيز لابن عطية /2؟ (اء، وانظر الجامع لأحكام }
\end{aligned}
$$

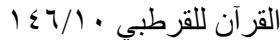

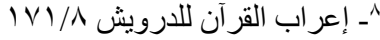

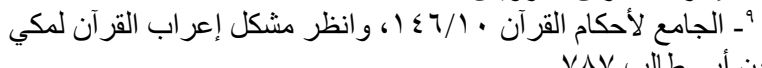

المثال الثالث: قال تعالى: "وإني أخاف عليكم عذاب

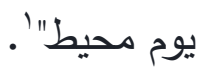
ذكر السمين الحلبيَ أن (محيط) صفة لليوم، وقد أُخذ من قولهم: أحاط به العدو، و أيضا من قوله تعالى: (وأُحيط بثره) مأن والإحاطة -كما يظهر - بينها وبين العذاب تلازم أكبر من علاقتها باليوم، وقد أشار إلى ذلك ابن عطية، حيث قال: "وُصف اليوم بالإحاطة، وهي من صفة العذاب على جهة التجوز ، إذ كان العذاب في اليوم. وقد يصح أن يوصف اليوم بالإحاطة على تقدير: محيط شره، ونحو هذا".

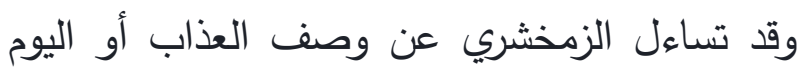
بالإحاطة، أيهما أبلغ؟ فأجاب بقوله: "بل وصف اليوم بها؛ لأن اليوم زمان

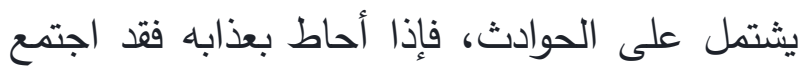

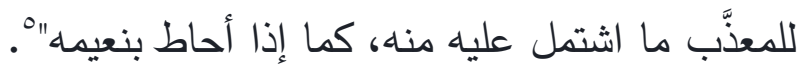
يقصد أن يوم العذاب إذا أحاط بهم فقد أحاط بهم

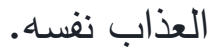
المثال الرابع: قوله عزَّ وجلّ: "عاليهح ثياب سندس

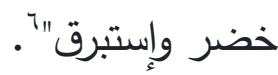
يظهر في هذه الآية صفتان هما: (خضر وإستبرق)، لحقتا بالمتضايفين: (ثياب سندس)، وجاءت فيهما قراءات متعددة، أشهرهما الرفع والجر. ولعلي في 
قال أبو حيان: " ويظهر أن (سبح) يتعدى تارة بنفسه،

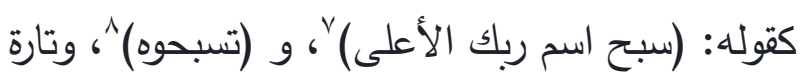
بحرف الجر، كقوله: (فسبح باسم ربك العظيم)، والعظيم يجوز أن يكون صفة لاسم، ويجوز أن يكون

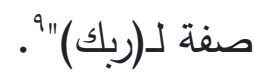
وعلّل السمين الحلبي كون هذه الصفة تصلح أن تكون

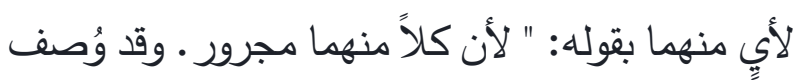

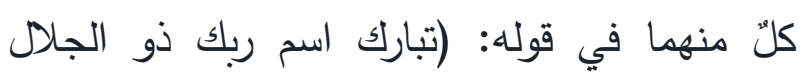

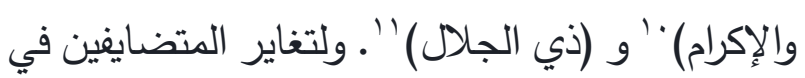

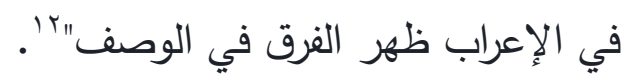

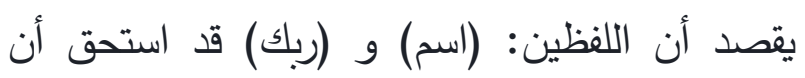

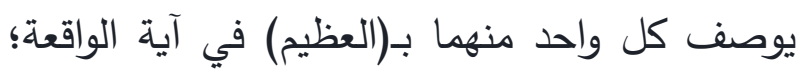

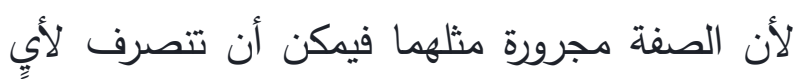

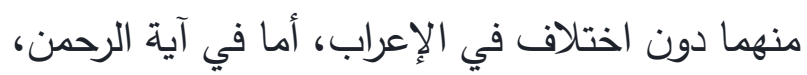

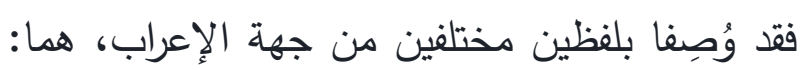
(ذو الجلال) و (ذي الجلال)، على أن الأخير منهما

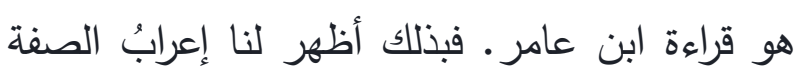
كنه الموصوف ونوعه. المثال السادس: آيتان متشابهتان، في سورتين مختلفتين، ويقع الاختلاف بينهما في جنس الصفة فقط، أي من ناحية التنكير والتأنيث، كما هو الحال في المثال السابق، ومن خلال هذا التغاير يتضح لنا الموصوف؛ لأن الصفة تتبع الموصوف.

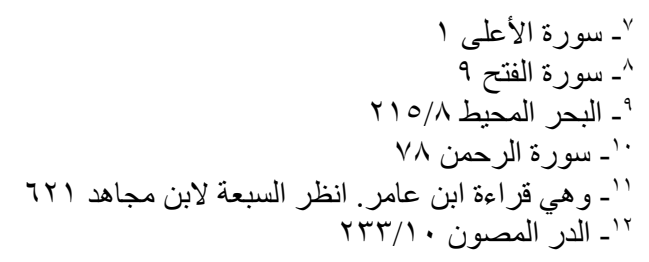

ثم ذكر القرطبي بعد ذلك قراءتي الرفع والجر فيهما جميعا، وبين توجيههما النحوي، حيث قال: "وقرأ نافع وحفص كلاهما بالرفع، ويكون (خضرٌ) نعتاً للثياب،

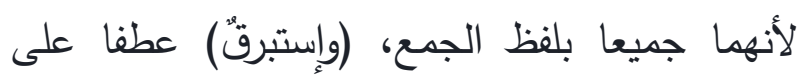
الثياب. وقرأ الأعمش وابن وثاب وحمزة والكسائي

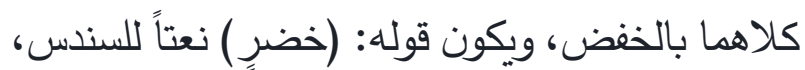
والسندس اسم جنس، وأجاز الأخفش وصف أفض اسم

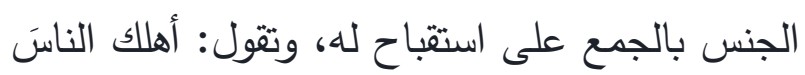

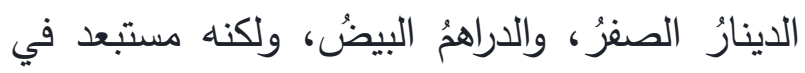
الكلام. والمعنى على هذه القراءة: عاليهم ثيابُ سندسٍ وليّ

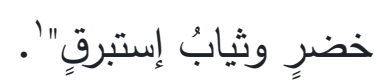
وربما في هذا المثال نقلت معظم كلام القرطبي -وإن طال- لما فيه من فوائد جمة تبين سعة هذه اللغة

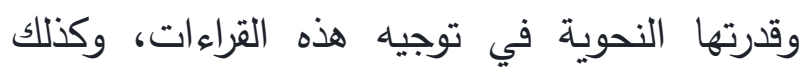
لإعطاء صورة واضحة للصفة التي تتبع أكثر من فن ونهاء موصوف، وأيضاً للإلمام بما قيل من معانٍ متعددة

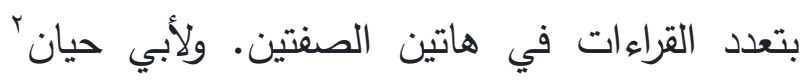
والسمين الحلبي كلام جميل في هذه الآية، لا يقل

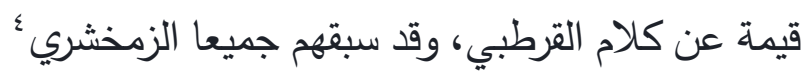
وابن عطية بْ بمثل ذلك. المثال الخامس: قوله سبحانه: "فسبح باسم ربك العظيم" - المتال
'ـ المصدر السابق.

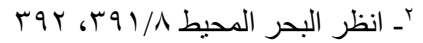

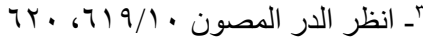

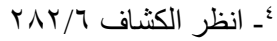

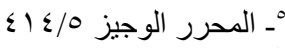
' - سورة الو اقعة 97 
و قال الدرويش: "وجملة (يفسدون) صفة لـ (تسعة)،

و (لا يصلحون) عطف على (يفسدون)" ل

تبين لنا من خلال الأمثلة القرآنية السابقة أن الصفة التي تلي المتضايفين، سواء كانت مفردة أو جملة، يستأثر بها أحدهما حسب المعنى، أو حسب القرائن التي تظهر على الصفة من إعراب أو جنس أو عدد، وقد تصلح أن تلحق بأيٍ منهما لتطابقهما في الصفات. والهدف من ضرب هذه الأمثلة هو التأكيد على أن وجود صفة بعد أكثر من موصوف هو أسلوب جارٍ في العربية، وقد جاء في مواضع عديدة من القرآن الكريم. وتبين لنا من هذا العرض أنه لا يتعين الموصوف أو صاحب الصفة، إلا من خلال المعنى ونى العام، أو عن طريق ضبط هذه الصفة إعرابيا، أو اقترانها بما يدل على صاحبها كالجنس والعدد. وقد تقدم معنا أن المتكلم هو الذي يوجه الصفة لموصوفها الذي تستحقه حسب المعنى الذي يريده.

\section{الخاتمة}

قامت الدراسة في هذا البحث على تفسير قوله تعالى: "ذو العرش المجيد"، وإبراز ما في هذه الآية من معانٍ وقراءات متعددة، وما تبع ذلك من توجيهات نحوية مختلفة لهذه القراءات. وركزَت على مدى جواز إلحاق صفة (المجيد) بـ (العرش). وهل هذه الصفة مختصة بالله عزّ وجلّ، أم يمكن إطلاقها على المخلوقات

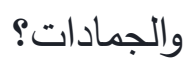

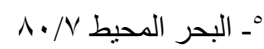

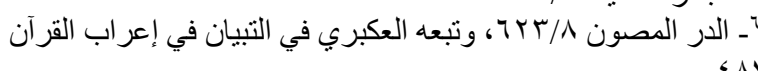

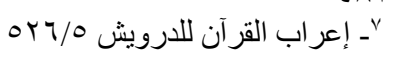

وهما: قوله تعالى: "ذوقوا عذاب النار الذي كنتم به تكذبون"' . وقوله سبحانه: "ذوقوا عذاب النار التي كنتم

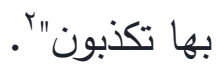
فالموصوفان هما المضاف والمضاف إليه: (عذاب النار)، والصفتان بعدهما: (الذي والتي)، فتحدد الموصوف في الآية الأولى بأنه (عذاب) من خلال لفظ الصفة الذي لحقه، وهو: (الذي)، وعرفنا الموصوف في الثانية أنه (النار)؛ لأن الصفة التي

$$
\text { لحقته هي: (التي). }
$$

وقد ذكر أبو حيان سبب مجي الوصف في آية السجدة للعذاب، في حين مجيئه في آية سبأ للنار ، حيث قال: "أنهم هنا لم يكونوا متلبسين بالعذاب، بل ذلك أول ما رأوا النار ، إذ جاء عقيب الحشر ، فوُصِفَت لهم النار بأنها هي التي كنتم تكذبون بها. وأما الذي في السجدة فهم مُلابسوا العذاب، مترددون فيه... فوُصِف لهم العذاب الذي هم مباشروه" . المثال السابع: قوله عزّ وجلّ: " وكان في المدينة تسعة رهط يفسدون في الأرض ولا يصلحون" . ذكر أبو حيان أن جملة (يفسدون) صفة لـ (تسعة رهط)، ولم يخصصها للمضاف أو للمضاف إليهء. ولكن السمين الحلبي فصّل بقوله: "قوله: (يفسدون) يجوز أن يكون نعتاً للمعدود أو العدد، فيكون في موضع جر أو رفع"'.

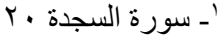

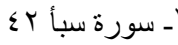
_ البحر المحبط

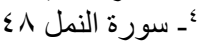


يدل على كثير من صفات الكمال، كالسعة والزيادة والكثرة، ونهاية الكرم والثرف والفضل، وكثرة العطاء.

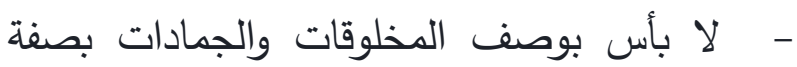
(المجد) ومشتقاتها، كما ورد في كلام العرب شعرا

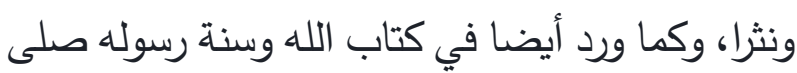
الله عليه وسلم، وليس مقتصرا على الخالق سبحانه؛ ولكن مجدهم غير مجده غير مجده عزَّ وجلَّ، كما هو الحال في العظمة والكرم وغيرهما. - لا يجيز البصريون إضافة الموصوف لصفته؛ وفئه لئلا يلزم إضافة الثيء إلى نفسه.

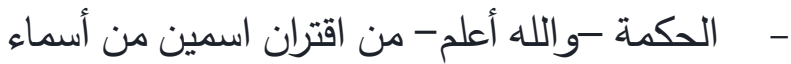
الله تعالى مع بعضهما هو حصول صفات متعددة

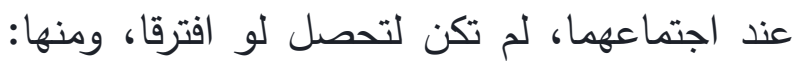
(الحميد المجيد) و (العزيز الحكيم) و (العليم الخير)، لحنها،

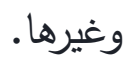

- تعدد الأوجه الإعرابية في كلمة (المجيد) في قوله تعالى: "ذو العرش المجيد"، ناتج عن تعدد القراءات.

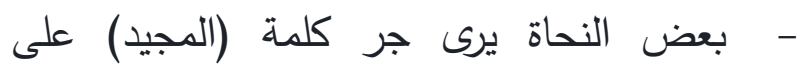

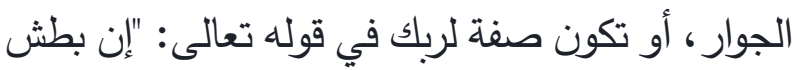

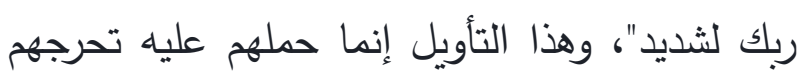
من أن يوصف العرش بالمجيد، والله أعلم. - الجر بالمجاورة مسألة خلافية بين النحاة، ولعلنا نفرد لها بحثا مستقلا في دراسات قادمة. - - يستشهد بهذه الآية (ذو العرش المجيد) في جواز

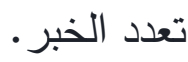

وأشارت هذه الدراسة أيضا إلى مسألة نحوية لها صلة

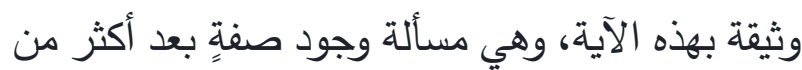

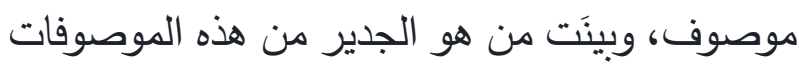
بالظفر بهذه الصفة، ثم خلصت الدراسة للنتائج التالية:

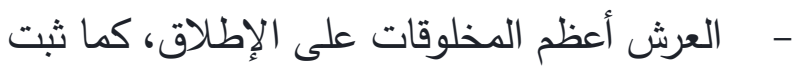
ذلك بالأدلة. - - إضافة العرش إلى الله في أكثر من آية زادته تشريفا وتكريما. - معظم الآيات بل كلها التي يرد فيها لفظ (العرش) معات أو مشتقاته يدور معناها على التعظيم والتتزيه، والعلو

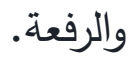

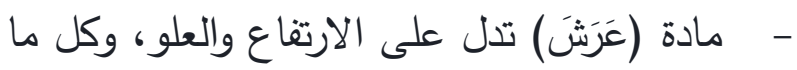
تفرع عنها يندرج تحت هذا المعنى. - لفظة العرش في كلام العرب لها معانٍ عدة، منها لهان أنه: سرير الملك، وسقف البيت، وعرش البئر، والسلطان والملك، وعرش القدم، أي: ظاهرها.

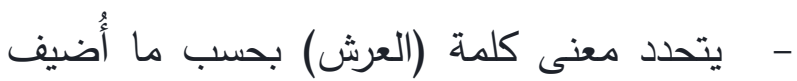
إليها، أي بحسب سياق الكلام. - ل غ غرابة في وصف العرش بالعظيم والكريم والمجيد، فهو أعظم المخلوقات وأكبرها، وكيف لا يكون كذلك! وقد أضافه الله إلى نفسه تشريفا له، وعلوا لمكانته، بل زاد على ذلك أن قربه منه، واستوى عليه

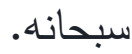
- المجد في كلام العرب ليس صفة مجردة، بل هو عبارة عن اجتماع صفات، مع اتساعٍ وكثرة فيها، فهو 
-V

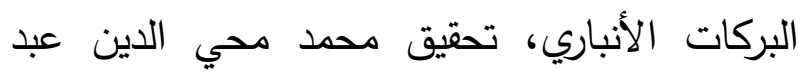

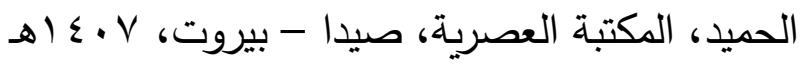

$$
\text { .) } 91 \mathrm{~V} \mathrm{-}
$$

1- بدائع الفوائد، لابن القيم، تحقيق علي بن محمد

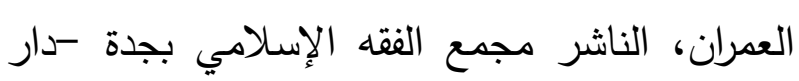

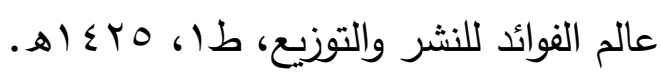
9- البداية والنهاية، لابن كثير الدمشقي، اعتنى به

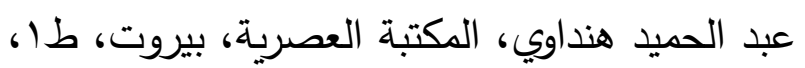
. • 1-البرهان في علوم القرآن، للزركشي، تحقيق مصطفى عبد القادر عطا، دار الكتب العلمية،

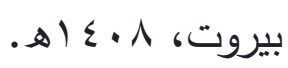
1ا-البحر المحيط، أبو حيان الأندلسي، تحقيق وتعليق عادل أحمد عبد الموجود ومجموعة من ل

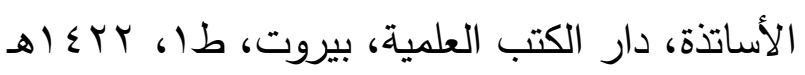
. r ا-البيان في غريب إعراب القرآن، لأبي البركات الأنباري، تحقيق طه عبد الحميد طه، دار الكاتب الب الب البركات

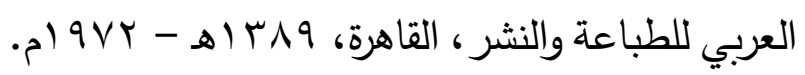
rا-تاج العروس من جواهر القاموس، للزبيدي،

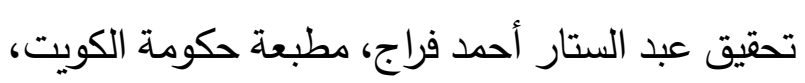

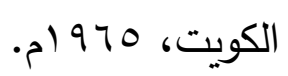
ـ ا- التبيان في إعراب القرآن، لأبي البقاء العكبري،

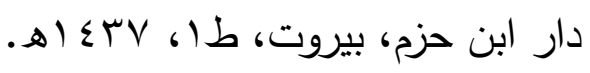

- وجود صفة بعد أكثر من موصوف هو أسلوب جارٍ في العربية، وليس بغريب عنها.

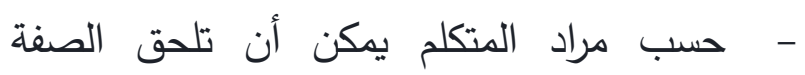
بالمضاف أو المضاف إليه إذا كانا قابلين للنعت.

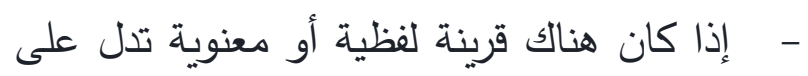

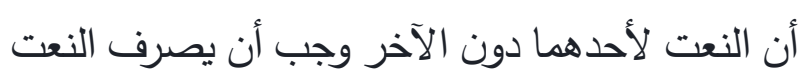
لمستحقه. المراجع

المصادر والمراجع - (المانع 1- الإتقان، للسيوطي، تحقيق محمد أبو الفضل،

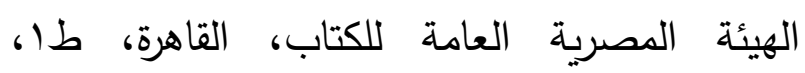

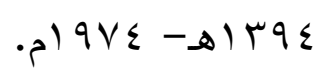
r- الأسماء والصفات، للبيهقي، تحقيق صالح بن

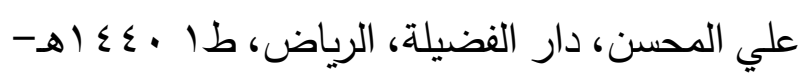
. ץ- الأسنى في شرح أسماء الله الحسنى، للقرطبي، تحقيق عرفان بن سليم العشا، المكتبة العصرية،

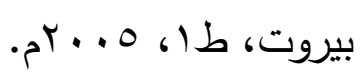
ع - إعراب القرآن، لأبي جعفر النحاس، تحقيق زهير

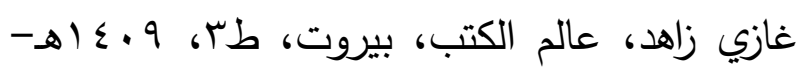
. 1911 ه- إعراب القرآن الكريم وبيانه، محي الدين الدرويش،

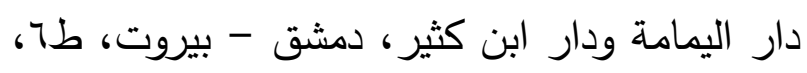
. 999 - ه ان 199 צ- الأعلام، للزركلي، دار العلم للملايين، بيروت، طه ( 
rץ-الحجة في علل القراءات السبع، لأبي علي الفارسي، تحقيق محمد إبراهيم سنبل وآخرَين، دار

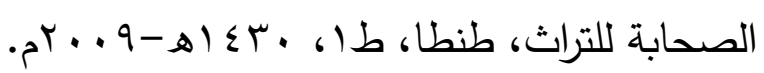
ع ז-حجة القراءات، لابن زجلة، تحقيق سعيد

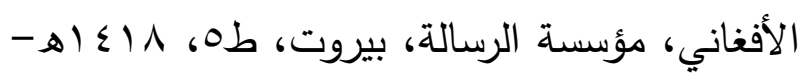
. $199 \mathrm{~V}$

ه

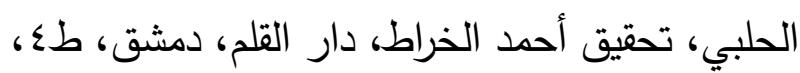

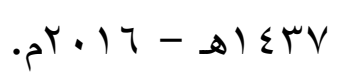

جץ-دفاع عن القرآن-أصالة الإعراب ودلالته على المعنى، محمد حسن حسن جبل، البربري للطباعة

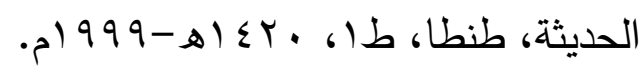

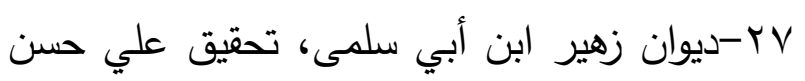

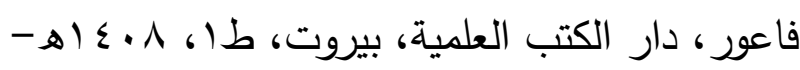
. 1911 ^ץ-ديوان عروة بن الورد، تحقيق أسماء أبو بكر

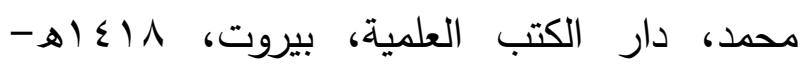
.01991 و ج-روح المعاني في تفسير القرآن العظيم، للألوسي، تحقيق علي عبد الباري عطية، دار الكتب العلمية،

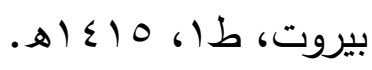
• ب-السبعة في القراءات، لابن مجاهد، تحقيق شوقي

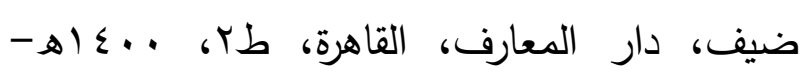
. 191 .
10-التبيان في أيمان القرآن، لابن القيم، تحقيق عبد

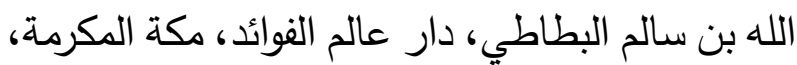
ط) מ ا ه 7 ا-تفسير الطبري، لابن جرير الطبري، تحقيق عبد الله بن عبد المحسن التركي، دار هجر للطباعة لإني

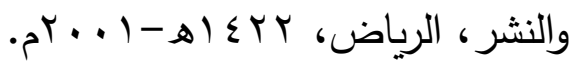

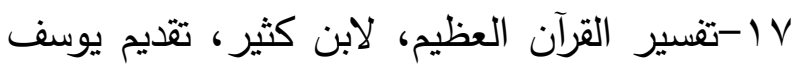

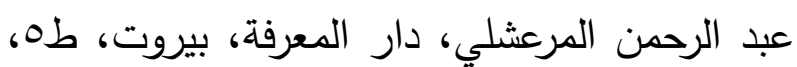
. $994-81 \leqslant 14$ 1 1-الجامع لأحكام القرآن، للقرطبي، اعتنى به هشام

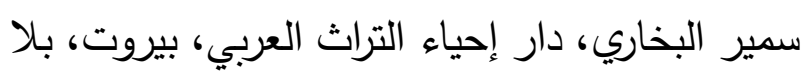
تاريخ. 9 1-الجامع لشعب الإيمان، للحافظ للبيهقي، تحقيق

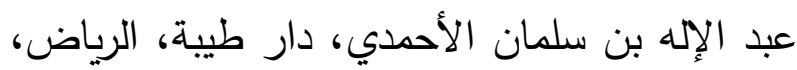
. (ا) • ץ- الجدول في إعراب القرآن وصرفه، لمحمود

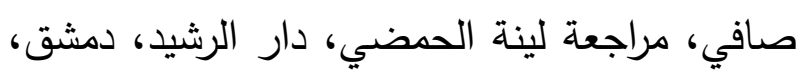

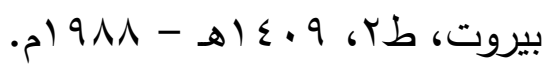

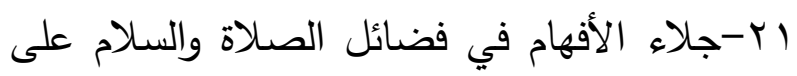
خير الأنام، لابن القيم، تحقيق زائد النشيري، الناشر

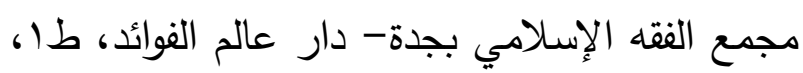
. ا) $1 \leqslant 0$ rY-جمهرة الأمثال، لأبي هلا العسكري، تحقيق محمد أبو الفضل وعبد المجيد قطامش، المؤسسة لإستال

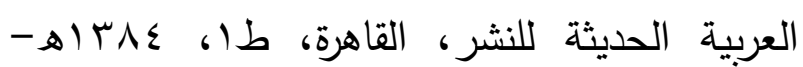


• ـ-صحيح مسلم، تحقيق محمد فؤاد عبد الباقي، دار إحياء التراث العربي، بيروت، بلا تاريخ.

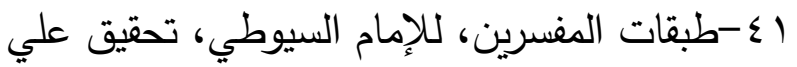
محمد عمر، مكتبة وهبة، القاهرة، طا، 97 بالهـ.

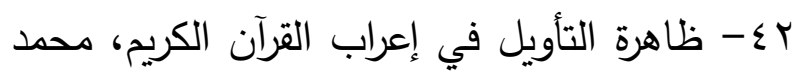
عبد القادر هنادي، مكتبة الطالب الجامعي، مكة

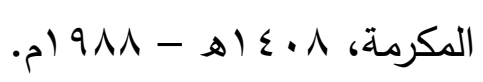

rی-فتح الباري بشرح صحيح البخاري، لابن حجر

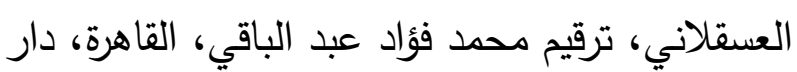

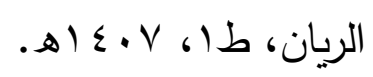

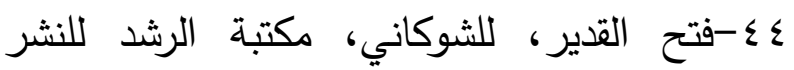

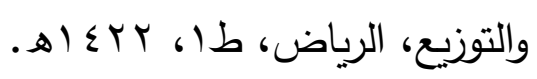

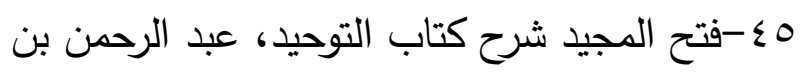
حسن بن محمد بن عبد الوهاب، تحقيق أشرف عبد

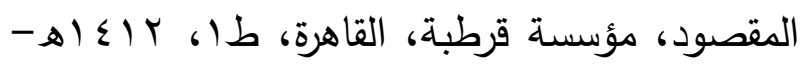

דء- القاموس المحيط، للفيروزآبادي، تحقيق مكتب

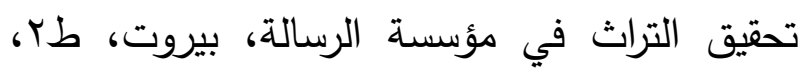

$$
\text { . } 9 \Lambda \vee-ه ~ \& . V
$$

V V

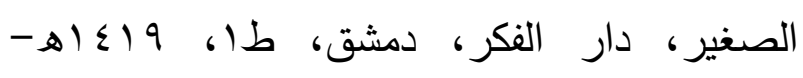
.01999

^ــ-كافي المحتاج إلى شرح المنهاج (شرح منهاج

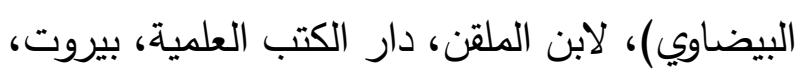

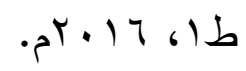

اب-شرح أشعار الهذليين، لأبي سعيد السكري، تحقيق

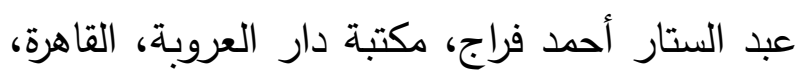
بلا تاريخ. rr-شرح ديوان الحماسة لأبي تمام، شرح المرزوقي،

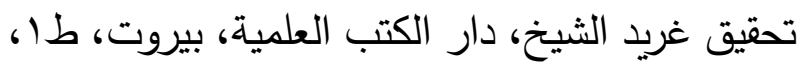
. $r$. . بr-شرح شذور الذهب، لابن هشام، اعتنى به أحمد

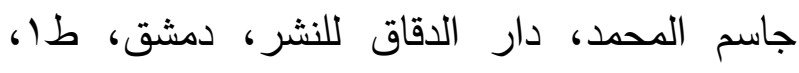
$.5 r+|9-8| \leq \varepsilon$. ع ז-شرح صحيح مسلم، للإمام النووي، دار إحياء

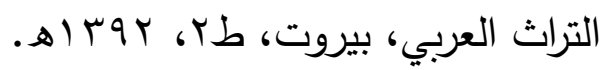

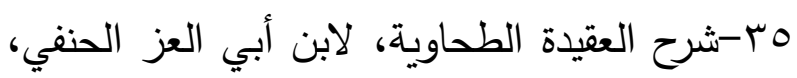

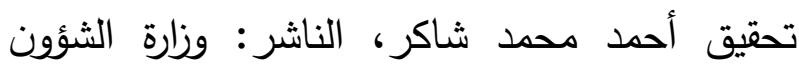
الإسلامية والأوقاف، السعودية، الرياض، 1 إع اهـ. جب-شرح القواعد المثلى في صفات الله وأسمائه الحسنى، للشيخ محمد بن صالح العثيمين، تحقيق العن

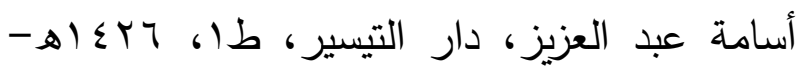
.5 صالح-شرح لمعة الاعتقاد لابن قدامة، شرح محمد بن

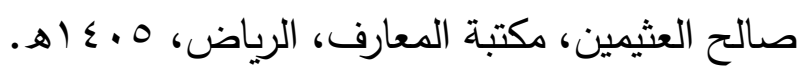
رr-صحيح ابن حبان، تحقيق شعيب الأرنؤوط،

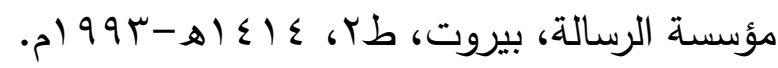
q"- صحيح البخاري - مختصر الزبيدي - تحقيق

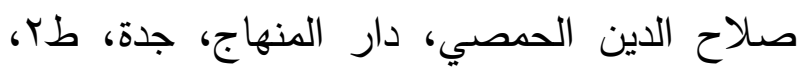
. 
-OV

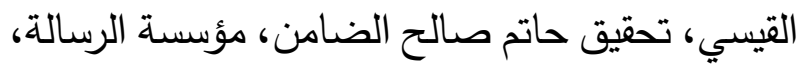

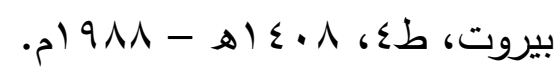

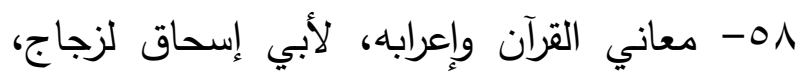
تحقيق عبد الجليل عبده شلبي، عالم الكتب، بيروت،

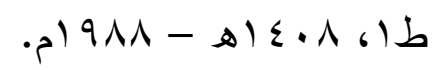
ه-معجم مقاييس اللغة، لابن فارس، تحقيق عبد

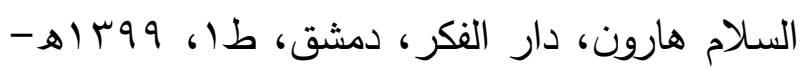
. $19 \vee 9$ • ؟-مغني اللبيب عن كتب الأعاريب، لابن هشام، تحقيق مازن المبارك، ومحمد علي حمد الله، دار

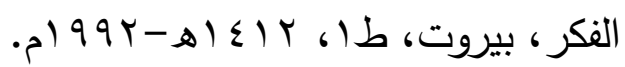

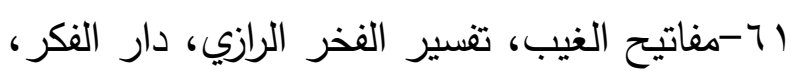

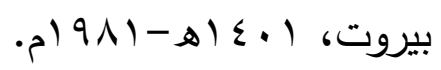
r ب-مفردات ألفاظ القرآن، للراغب الأصفهاني، تحقيق

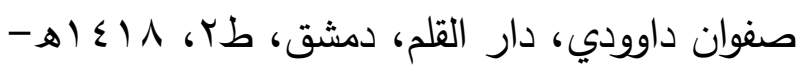
. $99 \mathrm{~V}$ سج- المقرب، لابن عصفور ، تحقيق أحمد عبد الستار

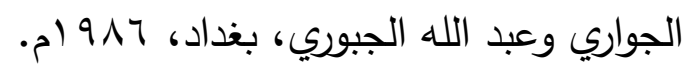

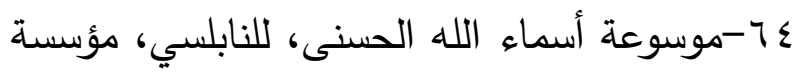

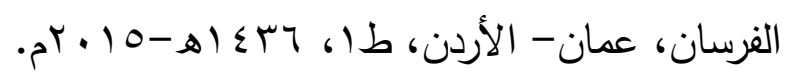
07-النحو الوافي، عباس حسن، دار الاردن، طار، المعارف، القاهرة، طه ا، بلا تاريخ. 77-نيل الأوطار، شرح منتقى الأخبار، للشوكاني، تارئ

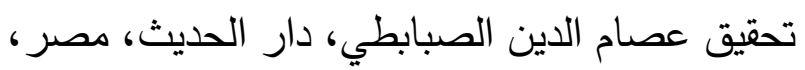

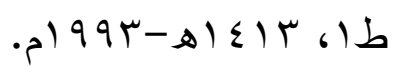

9 - الكتاب لسيبويه، أبي بشر عمرو بن عثمان بن قنبر ، تحقيق عبد السلام هارون، دار الجيل، بيروت، طا • ه-كتاب العين، للخليل بن أحمد الفراهيدي، تحقيق. مهدي المخزومي، وإبراهيم السامرائي، مؤسسة دار الهجرة، إيران، 9 •ـ اهـ. 10- الكثاف، للزمخشري، تحقيق عادل أحمد عبد إندان

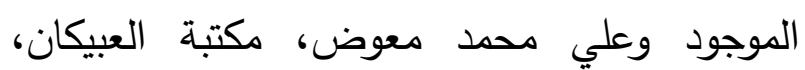

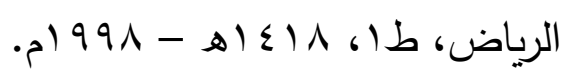
ror ل لسان العرب، لابن منظور ، طبعة دار المعارف، القاهرة، بدون تاريخ. ror-المتواري على أبواب البخاري، لأحمد بن محمد

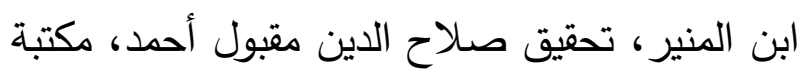

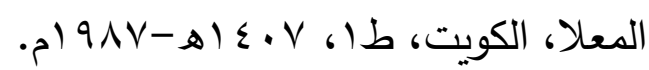
ـه-مجمع الأمثال، لأبي الفضل أحمد بن محمد اهل

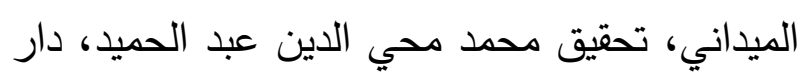
المعرفة، بيروت، بلا تاريخ.

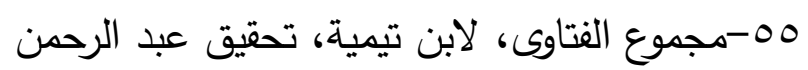

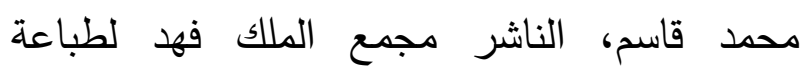

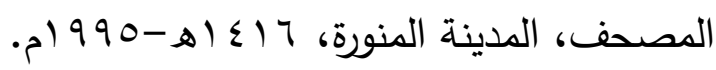
40 - المحرر الوجيز في تقسير الكتاب العزيز، لابن

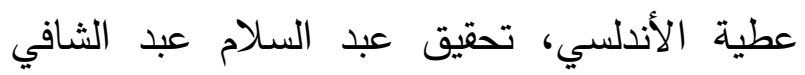

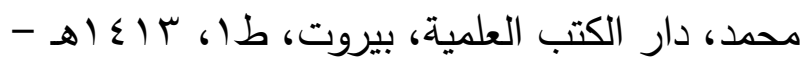
. 


$$
\begin{aligned}
& \text { VIT- همع الهوامع في شرح جمع الجوامع، لجلال } \\
& \text { الدين السيوطي، تحقيق أحمد شمس الدين، دار الكتب }
\end{aligned}
$$

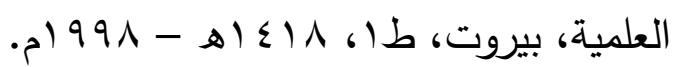

\title{
'POSSIBILITY TO ADD ADJECTIVE TO GENITIVE IN ALLAH'S SAYING 'DHU AL-ARSHEL MAJEED',
}

\author{
Dr. Abdullah Salem Althomali \\ Assistant professor \\ King Abdulaziz University \\ Faculty of Art/Arabic department
}

\begin{abstract}
ALLAH with glorification in terms of linguistic sense; and further to respond to those who denied such description shown in the Quranic verse claiming that such description would not be for anything but for ALLAH. To this aim, the study has relied upon two main axes as shown below:

- Axis I: is concerned with the meaning of 'Throne' (Al-Arsh) and 'Glorification' (Al-Majeed) in language, Quran and Sunnah
\end{abstract}

- Axis II: is intended to mention the viewpoints of scholars and interpreters who tried to interpret the verse; demonstrate the readings, attitude among grammarians towards such readings; and eventually highlighting the issue of adding an adjective to the genitive - and whichever is more right.

With the above-mentioned axes, the study concluded with several deliverables as indicated below.

- The term 'Throne' (Al-Arsh) has several meanings and senses among the Arabs' say. The exact sense and meaning of the said term is determined in accordance with the word added thereto.

- The term 'Throne' (Al-Arsh) refers to elevation and highness. Throne or Al-Arsh is the most prominent creatures at all - as proved by evidence

- Verses including the term 'Throne' or Al-Arsh or even its derivatives signal glorification, sublime and highness.

- Unsurprisingly, the Throne or Al-Arsh is described with glorification and highness since ALLAH annexes it to Himself in recognition for its sublime rank

- To Arabs, glorification is not a single adjective. Rather, it is a set of integrated characteristics signaling abundance, honor, generosity and giving.

- Glorification and its derivatives is used to depict creatures and thins - as noticed among Arabs - not confined to ALLAH. However, ALLAH's glorification is different than theirs - as is the case with other characteristics such as generosity and grandness.

- Wisdom - composed of conjunction of two names of ALLAH together - is having several characteristics when are combined together. Such characteristics would not emerge if separated. To name but a few is 'AlHameed Al-Majeed', 'Al-Aziz Al-Hakeem' and the like.

- Some grammarians see the term 'Al-Majeed' with a preposition to the next - most probably in order to remove the description of the throne annexed to it.

- Prepositional phrase is a controversial issue among grammarians. Such issue may be tackled later. 
- Perception experts do not tolerate addition of an adjective to the noun.

- This Quranic verse 'Dhu Al-Arsh Al-Majeed' is quoted to have multiple predicates.

- Unsurprisingly, having an adjective after several nouns is a prepositional style in Arabic language.

- An adjective is annexed to the adverbial phrase according to the intent of the speaker - if they could accept adjective.

- Should there be any verbal or corporeal term signaling an adjective to either, an adjective shall be then annexed. 